NBER WORKING PAPER SERIES

\title{
TAX POLICY AND EDUCATION POLICY: COLLISION OR COORDINATION? A CASE STUDY OF THE 529 AND COVERDELL SAVING INCENTIVES
}

\author{
Susan M. Dynarski \\ Working Paper 10357 \\ http://www.nber.org/papers/w10357 \\ NATIONAL BUREAU OF ECONOMIC RESEARCH \\ 1050 Massachusetts Avenue \\ Cambridge, MA 02138 \\ March 2004
}

I gratefully acknowledge support from NBER-National Institute on Aging Grants P30-AG12810 and K12AG000983. Naomi Calvo, Joe Ciesla, Betsy Kent and Juan Saavedra provided excellent research assistance. I thank Julie-Anne Cronin, Martin Feldstein, Andrew Samwick, James Stedman and participants in the NBER Taxation and Saving Conference and Tax Policy and the Economy Conference for helpful comments. This paper is forthcoming in Tax Policy and the Economy, Volume 18. The views expressed herein are those of the authors and not necessarily those of the National Bureau of Economic Research.

(C)2004 by Susan M. Dynarski. All rights reserved. Short sections of text, not to exceed two paragraphs, may be quoted without explicit permission provided that full credit, including (C) notice, is given to the source. 
Tax Policy and Education Policy: Collision or Coordination? A Case Study of the 529 and Coverdell Saving Incentives

Susan M. Dynarski

NBER Working Paper No. 10357

March 2004

JEL No. I22, H21, H24

\begin{abstract}
529 saving plans and Coverdell Educational Savings Accounts are marketed as attractive vehicles for college savings. The main finding of this paper is that college savings plans can actually harm some families. The joint treatment by the income tax code and financial aid system of college savings creates tax rates that exceed 100 percent for those families on the margin of receiving additional financial aid. Since even families with incomes above $\$ 100,000$ receive need-based aid, the impact of these very high taxes is quite broad. I find that an aid-marginal family with funds in a Coverdell is worse off than if it did not save at all. Simulations show that $\$ 1,000$ of pretax income placed in a Coverdell for a newborn and left to accumulate until college will face income and aid taxes that consume all of the principal, all of the earnings and an additional several hundred dollars. This perverse outcome is the product of poor coordination between the income tax code and the financial aid system.
\end{abstract}

Susan M. Dynarski

Kennedy School of Government

Harvard University

79 JFK Street

Cambridge, MA 02138

and NBER

susan_dynarski@harvard.edu 


\section{Introduction}

In the past few years, a new breed of tax-advantaged savings vehicle has emerged. The federal Coverdell Education Savings Account (ESA) allows annual, after-tax deposits of up to $\$ 2,000$ a year, with asset earnings untaxed so long as withdrawals are used for educational expenses. At the state level, nearly every state offers a tax-advantaged 529 savings plan. These accounts allow participants to make annual, after-tax deposits of up to $\$ 11,000$ a year per child, comparable to the annual ceilings on the 401(k). ${ }^{1}$ The tax treatment is like that of the ESA: earnings are untaxed by the federal government, and by almost every state, when the funds are used for postsecondary education. In about half the states, deposits are exempt from state taxation, further increasing the income tax advantages of the 529 .

Politicians and financial advisors aggressively market 529 saving plans and the ESA as attractive vehicles for college savings. For many families, the favorable tax treatment of these savings vehicles does make them more attractive than other methods of saving for college. However, as I show in this paper, some families are worse off saving in an ESA than they would be in an alternative savings vehicle, such as an IRA or even a non-tax-advantaged account. For families on the margin of getting more financial aid, holding funds in an education savings account will result in substantial decreases in aid eligibility. In the case of the ESA, more than a dollar in aid is lost for each dollar held in the account, more than undoing its tax incentive for saving and in fact leaving a family worse off than if it had not saved at all.

One might dismiss the results of the paper as irrelevant by observing that the poor get aid but do not save, and the rich save but do not get aid. This common wisdom is wrong. As I show in the next section, a substantial proportion of families with incomes above $\$ 70,000$, and even $\$ 100,000$, receive need-based aid, in the form of both grants and loans. Upper-income students at expensive, four-year private colleges often qualify for need-based grant aid from their schools, while even those at less-

\footnotetext{
${ }^{1}$ Each parent can deposit $\$ 11,000$ per child in a given year without triggering a gift tax. A two-parent family with three children could therefore move $\$ 66,000$ per year into a tax-advantaged 529 account. Grandparents can also make deposits up to these limits, further expanding the amount of assets that can be shielded from taxation. A five-year averaging option allows a participant to contribute $\$ 55,000$ in a single year without triggering a gift tax.
} 
expensive four-year public colleges often qualify for subsidized, need-based federal loans. These families are therefore subject to the aid policies I describe in the paper. Of course, such families also save, and so have assets that are affected by the intersection of tax policy and aid policy described in this paper.

That there is a tension between policies intended to increase saving and distribute aid according to need is unsurprising. The intent of the 529 and ESA is to increase saving by increasing after-tax returns. The intent of the need-based aid system is to give less aid to those with higher assets. These two sets of policies inevitably work at cross-purposes, because the aid system taxes away part of the increase in assets and asset returns that the savings incentives create. ${ }^{2}$ This tension between targeting funds to those who are most needy and discouraging desirable behaviors is an inherent characteristic of all meanstested programs. For example, the old welfare system had an earned income test: welfare benefits were reduced proportionally for each dollar earned. This acted as a tax on labor supply and theoretically discouraged work effort by welfare recipients. Similarly, the need-based aid system taxes increases in income and assets, thereby potentially discouraging saving.

Unless assets and asset income are completely disregarded in the distribution of need-based aid, the aid determination process inevitably reduces asset returns and perhaps saving rates. The conclusion of this paper is that the tension between targeting aid and discouraging saving can be managed well or poorly. For example, I find that that the aid system assesses different assets at very different rates, with the drop in aid associated with a dollar in assets ranging from 50 cents to nearly two dollars. This variation in asset treatment has a cost, because it distorts decisions about the composition of savings. There is no concomitant benefit, however, because these wildly varying policies do not improve the targeting of aid toward needy students. If anything, such arbitrary policy variation undermines the goals of need-based aid, in that families with identical financial positions receive very different levels of aid, depending on whether they are savvy enough to steer their savings toward the right vehicles.

\footnotetext{
${ }^{2}$ The aid tax was first discussed by Edlin (1993) and Feldstein (1995).
} 
It now appears that the Department of Education is moving to improve the treatment of the ESA documented in this paper. In early November, 2003, the department posted revisions to the online version of the Student Financial Aid Handbook, its reference manual of aid rules. These revisions indicate that, in the future, the ESA will be given the treatment currently applied to the 529 savings plans. This treatment will eliminate the so-called aid tax of over 100 percent that is currently applied to the ESA.

It is not clear when this new policy will become effective. Given how the department collects asset data from applicants, a necessary step in implementing the new policy is revision of the Free Application for Federal Student Aid (FAFSA). The FAFSA does not collect separate data on each type of asset; if it did, the department could change the formula that calculates aid eligibility without altering the FAFSA. Rather, the 2003-2004 FAFSA, which has not been revised, instructs families to add ESA balances to other miscellaneous student assets, while 529 balances are added to other parental assets. Parental and student assets are then run separately through the aid formula, with one dollar in student assets leading to a reduction in aid of more than one dollar over the course of a college career. Note that all student assets are subject to this treatment; changing the treatment of the ESA will still leave other student assets subject to the very high taxes that are the subject of this paper. The discussion in Section 6 speaks to this point.

The paper is organized as follows. In Section 2, I show that families quite high in the income distribution are affected by aid policy. In Section 3, I provide background on the tax-advantaged college savings plans. In Section 4, I calculate returns on various savings vehicles net of income taxes. In Section 5, I explain the aid determination process and calculate returns that accounts for both income taxes and the reductions in aid caused by holding savings in various vehicles. Section 6 discusses the results and Section 7 concludes.

\section{Who Is Affected by Aid Policy?}

What kind of family is affected by the aid system and its treatment of assets? Given the historically high level of tuition prices, relatively well-off families qualify for need-based aid, and so are 
affected by the aid rules. This is particularly true if the student attends a private college, or if a family has multiple students in college at the same time. ${ }^{3}$ As this section will show, families all along the income distribution are affected by the need-based aid system and its treatment of assets and asset returns.

For two kinds of families, however, the aid system's treatment of assets is irrelevant. The first type of family is extremely needy (as defined by the need-based aid system) and receives the maximum aid allowed. ${ }^{4}$ For this family, a marginal decrease in assets does not increase its aid, nor does a marginal increase in their assets decrease its aid. Since there is no link between assets and aid for this family, its net asset returns are unaffected by the aid system. The second type of family is at the other end of the spectrum: this family is very well off (again, as defined by the need-based aid system) and receives no aid. Again, marginal changes in assets will not affect this family's aid eligibility. For any family that is not at one of these two extremes of need, asset returns are affected by the rules discussed in this paper.

\subsection{Who Gets Aid?}

Families all along the income distribution get financial aid. Table 1 shows the probability that a student with a given family income will receive need-based aid, and the average amount of aid received among aid recipients. These data are for non-foreign, full-time, dependent undergraduates attending a single college in academic year 1999-2000 and are taken from the 2000 National Postsecondary Aid Survey (NPSAS). I show results separately for four categories of need-based aid: 1) all types, including grants, loans and work-study 2) federal Pell Grants only 3) need-based grants provided by colleges and 4) subsidized federal loans.

\footnotetext{
${ }^{3}$ A family that has multiple children in college at a given point in time is eligible for more need-based aid than if those children attended college in sequence.

${ }^{4}$ Total aid is capped by a student's actual schooling costs, which includes tuition and fees plus an allowance for items such as food, rent, and other living expenses.
} 
Low-income families are most likely to receive aid, and get the largest aid packages. ${ }^{5}$ Among students with family incomes below $\$ 40,000,85$ percent receive need-based aid, with their total aid packages averaging $\$ 6,859$. However, middle- and even upper-income families are quite likely to receive substantial amounts of aid. Of students from families with incomes of $\$ 40,000$ to $\$ 70,000,62$ percent receive need-based aid in the form of grants, loans or work-study, with the aid of recipients averaging $\$ 5,937$. Moving up the income distribution, we see that 37 percent of students from families with incomes of $\$ 70,000$ to $\$ 100,000$ receive need-based aid averaging $\$ 5,371$. Even in the highest income group, 22 percent of students receive some form of need-based aid, averaging $\$ 4,975$.

The composition of this need-based aid varies considerably across the income groups. Pell Grant distribution is highly progressive. While 68 percent of students from families with income below $\$ 40,000$ receive a Pell Grant, only nine percent of students from families with incomes of $\$ 40,000$ to $\$ 70,000$ receive a Pell, and no students in higher income categories. While the Pell is heavily concentrated among low-income students, the story is quite different for other forms of need-based aid. Colleges and universities, especially the more-expensive private schools, distribute their own need-based scholarships. The more expensive the school, the more likely that a student of a given income level will qualify for need-based aid from that school. Among students with family income below \$40,000, 26 percent receive need-based grants from their schools, with the grant of recipients averaging $\$ 4,074$. In the next-higher income category, the share receiving a need-based grant drops barely, to 24 percent, while the average grant received rises to $\$ 5,060$. This reflects the tendency of these higher-income families to send their children to expensive schools. Even among families with incomes above $\$ 100,000,12$ percent receive need-based grants from their schools averaging $\$ 4,617$ per grant. $^{6}$

\footnotetext{
${ }^{5}$ Note that the average amount of need-based aid does not drop very rapidly with income. This is because higher-income students are more likely to attend expensive private institutions, and need is a function of both ability to pay and actual schooling costs.

${ }^{6}$ Most schools follow the federal formulas described in this paper in distributing their own need-based grant. Eighty-seven percent of four-year public schools and 57 percent of four-year private schools use the federal formula in distributing their own need-based grants (see National Association of Student Financial Aid Administrators and the College Board, 2002).
} 
Many middle-and upper-income students also qualify for need-based, subsidized federal loans. While loans are obviously less valuable than grants, the need-based Perkins and Stafford loans have very attractive terms, with all interest paid while the child is in school and a low rate of interest paid thereafter. The subsidy value of a need-based Stafford loan is currently about thirty cents on the dollar. ${ }^{7}$ In the $\$ 40,000$ to $\$ 70,000$ income range, 49 percent of students receive one of these federal loans, with annual borrowing averaging $\$ 3,419$, not very different from the borrowing patterns in the lowest income group (52 percent borrowing, with loans averaging $\$ 3,835$ ). Even in the highest income category the figures are 12 percent and $\$ 3,518$, respectively.

\subsection{Who is on the Margin of Getting More Aid?}

Many of these families who receive need-based aid are on the margin of getting more aid - that is, an increase (decrease) in their financial resources decreases (increases) the amount of aid for which they are eligible. So too are those families who currently get no aid at all but would if their financial resources, as defined by the aid system, were to decrease. We can get a sense of how many students are on the aid margin by examining the population of current students, and in particular those who apply for financial aid. Note that who applies for aid is almost certainly influenced by individuals' expectations about whether they will qualify for aid and how much they might receive. For example, an upper-income family with substantial funds in an ESA might not apply for aid under the current policy regime, but would if the aid system treated ESAs differently. By using data from those students who apply for aid to estimate the share of all students who are on the margin of aid I underestimate the share of the student

\footnotetext{
${ }^{7}$ See Dynarski (2002). The bulk of the subsidy arises from the government paying the interest on the loan while the student is in school. The subsidy value on the Stafford is at a historical low, since market interest rates are quite low. As market interest rates rise, so too does the subsidy value. The subsidy value rises especially rapidly when market rates exceed the statutory rate cap of 8.25 percent, as above this rate the government assumes all interest rate risk.
} 
population that would be affected by a change in the aid formula, since I do not account for such endogenous changes in the extensive aid margin. ${ }^{8}$

Describing who is on the aid margin requires some understanding of how the need-based aid system defines need. As I will describe in greater detail later in the paper, need is determined by comparing a student's projected schooling costs with the amount that the aid formula determines that her family can afford to pay toward college. This latter amount is referred to as the expected family contribution (EFC). Need is defined as schooling costs minus the EFC.

Two types of students are on the aid margin: 1) those receiving no aid who would receive aid if their financial situation changed marginally (these students have non-positive need) and 2) those receiving some aid who would get more or less aid if their financial situation changed marginally (these students have positive need). I treat these two cases in turn.

A student with non-positive need is not eligible for need-based aid, because the aid formula calculates that he and his family can handle the full cost of college. Those with very negative need (EFC $>>$ schooling cost) are far from the aid margin, because the aid formula indicates that they can contribute an amount well above schooling costs; such families are not on the aid margin. But for those whose need is relatively small and negative, marginal decreases in their financial resources push them over the margin into aid eligibility.

At the bottom of Table 1, I show the share of students in each income category whose need lies between 0 and $-\$ 5,000$. For these students, changing the formula so that their expected family contribution drops by $\$ 5,000$ or less pushes them over the margin into receiving aid. To get a sense of the magnitude of this change in EFC, note that a high school senior whose family has $\$ 15,000$ of college savings in a Coverdell ESA or UTMA (Uniform Transfer to Minors Act) account has a freshman-year

\footnotetext{
${ }^{8}$ Note that, in the calculations that follow, when a student does not have EFC information, as is the case for anyone who has not applied for aid, I have assumed that she is not on the margin of getting aid.
} 
EFC about $\$ 5,000$ higher than a senior whose family has no college savings. ${ }^{9}$ The lowest-income families (less than $\$ 40,000$ ) are always eligible for some form of need-based aid, so none of them are on this aid margin. However, six percent of students from families in the $\$ 40,000$ to $\$ 70,000$ income range, and 14 percent of those in the $\$ 70,000$ to $\$ 100,000$ income range, would be pushed into aid eligibility by a decrease in their EFC of $\$ 5,000$ or less. In the highest income group, eight percent are on this aid margin. ${ }^{10}$

Another type of family is getting some need-based aid but would get more if their EFC dropped. These families have positive need, but they are not so needy that changes in their financial situation cannot increase or decrease their aid package. I define these families as those whose EFCs are sufficiently far from zero (at least $\$ 5,000$ ) that they will see substantial changes in need if their financial resources (as defined by the aid system) alter. For such families, dollar decreases in need translate into dollar increases in aid. For example, their need can increase by at least $\$ 5,000$ without bumping up against the ceiling of the student's total schooling costs. ${ }^{11}$ Again, few low-income students are on this aid margin - just four percent. However, about forty percent of students in the $\$ 40,000$ to $\$ 100,000$ income group have room for their need to grow by at least $\$ 5,000$. Nineteen percent of students in the top income group fall on this aid margin.

As the bottom row of Table 1 shows, a substantial share of families fall on one of these two aid margins. Roughly half of students from families with income between $\$ 40,000$ and $\$ 100,000$ are on the margin of getting more aid, as are a quarter of those from families with income above $\$ 100,000$. The

\footnotetext{
${ }^{9}$ As I will show later in the paper, the aid eligibility of subsequent years of college is also negatively affected by this ESA account, so the ultimate impact of ESA and UTMA holdings on aid is substantially larger than that described in this sentence.

${ }^{10}$ Note that the share of students on this margin is likely to be underestimated using data on aid applicants, as discussed above.

${ }^{11}$ This assumes that all need is met by some combination of loans, grants, and work-study provided by government and schools.
} 
interaction of aid policy and tax policy described in this paper therefore affects a large number of families.

\section{Income Tax Incentives for College Saving}

\subsection{Legislative History}

In 1997, the Education IRA was established. The Education IRA was structured much like the then-new Roth IRA. In both types of vehicles, after-tax dollars grow tax-free. Earnings are never taxed if Education IRA withdrawals are used for postsecondary expenses or if Roth funds are withdrawn after age $591 / 2$. Annual contributions to the Education IRA were capped at $\$ 500$ per child until 2001 , when the contribution limit was raised to $\$ 2,000$. The same year, eligible educational expenses were expanded to include primary and secondary education, and the name of the Education IRA was changed to Coverdell Education Savings Account (ESA).

While the ESA is a product of federal legislation, the 529 savings plans are innovations of the states. The 529 savings plans have their roots in prepaid tuition plans, the first of which was introduced by Michigan in 1986. Those who purchased shares in Michigan's plan were guaranteed that their investment would cover the cost of a certain number of semesters at Michigan schools. Essentially, Michigan created a savings plan whose rate of return was linked to tuition costs at the state's public postsecondary schools, thereby allowing parents to insure against the risk of rising tuition prices. ${ }^{12}$ Michigan exempted investment returns in its prepaid plan from state taxes, and the state argued to the Internal Revenue Service (IRS) that returns should also be exempted from federal taxes. The IRS disagreed, but Michigan went forward with the plan and sued the IRS for a refund of taxes paid, winning its case in 1994. While the Michigan case was wending through the courts, several other states introduced their own prepaid tuition plans.

\footnotetext{
${ }^{12}$ A key drawback of the prepaid plans is that the tuition guarantee is only for in-state schools. Funds can be used at out-of-state schools, but the implied rate of return on funds used in this way is quite low.
} 
In 1997, Congress codified in Internal Revenue Code (IRC) section 529 the federal tax treatment of the tuition plans, which was to tax earnings in these accounts only at withdrawal. IRC section 529 also contains language that recognized a variant on the prepaid plans that had been introduced by a handful of states: the tax-advantaged college savings plan. Like the Education IRA, these new savings plans allowed after-tax investments to grow free of federal and state taxes; however, withdrawals used for postsecondary costs were exempt only from state taxation.

With the passage of tax reform in 2001, the federal tax on withdrawals from 529 savings plans was eliminated. ${ }^{13}$ Every state except Washington now has a 529 savings plan, as does the District of Columbia. The growth of the 529 savings plans has far outstripped that of the prepaid plans, likely because of their greater fungibility and potentially higher returns. ${ }^{14}$ In this paper, I focus on the 529 savings plans.

\subsection{Eligibility for and Tax Advantages of the 529 and ESA}

The tax treatments of the ESA and 529 are quite similar: after-tax dollars put into savings and earnings are not taxed as they accrue, nor are they taxed at withdrawal if the withdrawal is used for educational expenses. ${ }^{15}$ However, there are some key differences between the two savings vehicles.

First, there is an income limit on participation in the ESA. Joint-filer households with incomes above $\$ 220,000$ and single-filer households with incomes above $\$ 110,000$ cannot contribute to an ESA;

\footnotetext{
${ }^{13}$ This federal tax treatment of the 529 savings plans sunsets in 2010 . The present analysis assumes that the provision will be extended indefinitely.

${ }^{14}$ The bull market of the 1990s made the tuition plans appear stodgy to investors accustomed to doubledigit returns. Also, the plans substantially constrain the college choices of beneficiaries, who can use the funds at out-of-state schools only at unattractive terms.

${ }^{15}$ As discussed below, some states exempt contributions to the 529 from state taxable income, thereby increasing the tax advantages.
} 
eligibility begins to phase out at $\$ 190,000$ and $\$ 95,000$, respectively. There is no income limit on contributions to a 529 savings plan. ${ }^{16}$

A second distinguishing characteristic of the 529 is that its contribution limits are much higher than the limit on the ESA. Each account owner (a parent or grandparent, for example) can put $\$ 11,000$ in after-tax income per beneficiary, per year, into a 529. ${ }^{17}$ A two-parent family with three children can put $\$ 66,000$ a year into 529 savings plans for their children, but just $\$ 6,000$ into ESAs. Each state has a lifetime limit on the account balance that can be reached in an account held in a given beneficiary's name. When the account reaches this limit, no additional contributions can be made. The limit averages $\$ 241,000$, and it ranges from $\$ 182,000$ in Louisiana to $\$ 305,000$ in South Dakota. ${ }^{18}$

Third, while families can invest their ESAs as they wish, they are constrained in their ability to allocate assets in a 529. Each state determines the investment options open to investors in its plan and, by federal law, assets can be reallocated by the investor only once a year. Until recently, most 529 savings plans provided only a single investment option, an age-based portfolio that grew less aggressive as the child neared college age. Most plans now offer several investment options.

Finally, the 529s are creatures of state government, with each state sponsoring its own plan. There is therefore heterogeneity across the states in 529 characteristics, including portfolio choice, tax treatment, and net returns. Each state contracts with a mutual fund company to run its plan; chooses the mutual funds that will be available to investors; decides upon the treatment of deposits and earnings for the purposes of state taxation; and negotiates fees that will be paid by the investor to the state and fund company. Individuals are free to participate in any state's plan. Many of the states encourage their residents to invest in the local plan by allowing them to deduct contributions to its 529 savings plan from

\footnotetext{
${ }^{16}$ In some states, the exclusion of contributions from state taxable income phases out as income rises. The exclusion of earnings from taxable income is not linked to income in any state.

${ }^{17} \$ 55,000$ per account owner, per year, can be deposited in a single year for a beneficiary if no deposits are made for the next four years.

${ }^{18}$ See Cerulli Associates, 2003.
} 
state taxable income. Some states also tax withdrawals from other states' 529 plans, further encouraging investors to choose their home state's plan.

There is considerable cross-state variation in fees charged on the 529 accounts. 529 fees also appear to be somewhat higher, on average, than fees on ESAs or retail mutual funds. For the purposes of this paper, I ignore this source of variation in net returns across states and savings vehicles. By assuming that pretax returns on the various savings vehicles are identical, we can focus on variation in returns driven by the income tax code and the aid system. In ongoing work, I explicitly focus on sources of crossstate heterogeneity in 529 returns and its impact on savings decisions.

\section{Calculation of After-Tax Returns on the ESA, 529 and Alternative Savings Vehicles}

In this section, I calculate returns, net of the income tax, on the 529 and ESA, in absolute terms and relative to other vehicles. I first show variation in net returns across vehicles for a single household type, with household income of $\$ 100,000$ and two dependent children. Since the benefits of taxadvantaged accounts vary with marginal tax rates, I then calculate returns for a range of household incomes.

\subsection{Assumptions}

For the purposes of assigning tax rates, I consider a household that consists of a married couple, filing jointly, with two dependent children. All earned income is assumed to come from one earner. ${ }^{19}$ The children are assumed to have no income other than that produced by any college savings held in their name. The marginal federal and state tax rates on earned income, capital gains and interest for this household, as well as for the other income groups I will be analyzing, are shown in Table 2 . The state tax

\footnotetext{
${ }^{19}$ Some assumption about the distribution of earned income within the household must be made in order to assign FICA rates. For each earner, the FICA rate is 7.65 percent up to $\$ 87,000$ and 1.45 percent thereafter.
} 
rates in Table 2 are the average of the states' 2002 marginal tax rates for each income group, as calculated by the National Bureau of Economic Research's TAXSIM program. ${ }^{20}$

Table 2 shows, and the paper's calculations use, federal tax rates effective as of the Jobs and Growth Tax Relief Reconciliation Act (JGTRRA) of 2003. Some of these rates are scheduled to revert to pre-2003 rates in a few years. Since it is difficult to forecast which, if any, of these provisions will be allowed to sunset, in this paper I calculate the effect of making the current provisions permanent.

For each savings vehicle, I calculate the return to $\$ 1,000$ of pretax income placed in an account at the time of a child's birth. A family saving for college will likely start with a portfolio heavily weighted toward stocks, moving toward a more conservative mix as college nears. Every state's 529 savings plan offers an age-based portfolio that follows this pattern. I use a portfolio mix typical of state $529 \mathrm{~s}$ in calculating returns; this portfolio is shown in Table 3. I assume an identical portfolio mix for the other savings vehicles, so that any the variation in returns across the vehicles will be induced by variation in their treatment by the income tax and aid systems.

Stocks are assumed to earn a nominal rate of return of nine percent and bonds a rate of four percent. To simplify the analysis, I assume that all stock returns take the form of long-term capital gains. Capital gains are realized when the funds are withdrawn from the account in order to pay for college; these withdrawals begin at the end of the account's eighteenth year. ${ }^{21}$ After any relevant taxes on asset earnings are paid, earnings are reinvested.

In about half the states, deposits to the 529 are excluded from state taxable income. I calculate returns for 529s both with and without this upfront deduction. I also calculate returns for a non-taxadvantaged mutual fund account in the name of the parent, a Uniform Transfer to Minors Act (UTMA) account in the name of the student, and a Traditional IRA. Table 4 summarizes the income tax treatment

\footnotetext{
${ }^{20}$ The average is taken over the states that have an income tax. I use effective marginal state tax rates calculated by TAXSIM, rather than the bracket rates. The effective marginal rates account for the interaction of state and federal taxes as well as the phase-out of various credits and deductions.

${ }^{21}$ The family withdraws $1 / n$th of the remaining balance each year, with $n$ representing the number of years remaining until college completion. For the calculations in the paper, I assume four years of college.
} 
of these savings vehicles. For all vehicles, I assume that all capital gains realizations are put off until the account is drawn down, and that no dividends are earned. Therefore, the only relevant taxes on the inside buildup are those on bond interest. ${ }^{22}$ Note that the IRAs can be used for higher education expenses without the 10 percent penalty usually assessed on withdrawals before retirement age. However, the earnings portion of such early withdrawals from a Roth is subject to taxation as ordinary income. As a result, the Roth is not an advantageous vehicle for college savings if its use requires early withdrawal.

\subsection{Calculation of Returns Net of Income Taxes - Example}

I first calculate the nominal returns for a family with household income of $\$ 100,000$, using the assumptions laid out above. The return for a non-tax-advantaged mutual fund account, held in the name of the parent, forms the benchmark used to gauge the financial benefits of the tax-advantaged vehicles.

After paying Social Security and Medicare taxes (FICA), as well as federal and state income taxes, on $\$ 1,000$ of pretax income, this household has $\$ 673$ to deposit. The family uses the portfolio allocation shown in Table 3, putting 90 percent of the funds into stocks and the balance into bonds. Interest on the bonds is taxed as ordinary income; the interest net of taxes is reinvested in the account. After eighteen years, the account will have grown to $\$ 1,135$, with 55 percent of the account's value consisting of unrealized capital gains. At the end of year eighteen, one-quarter of the account balance is withdrawn to pay for college. Capital gains taxes are paid on the portion of this withdrawal that represents unrealized capital gains. After four years of withdrawals, the account is empty. Taking into account income and payroll taxes, as well as taxes on interest and capital gains, a family following the investment path just described nets $\$ 1,113$ on its $\$ 1,000$ in pretax saving, as shown in the first bar in Figure 1 and in Table 5.

The tax-advantaged vehicles, including the 529 and ESA, increase returns by reducing or eliminating the taxes assessed before the initial deposit, during the inside buildup, and/or at withdrawal.

\footnotetext{
${ }^{22}$ I assume that current tax law will persist despite the scheduled sunset of the exclusion of 529 earnings from federal taxable income.
} 
The return for each of these vehicles is shown in Figure 1. The second column of Table 5 shows the returns on assets held in these vehicles relative to returns for a non-advantaged account in the name of the parent. Below, I briefly discuss the tax advantages conferred by each of these vehicles.

The UTMA account shifts assets into the child's name and, thereby, the child's lower tax bracket. $^{23}$ The initial pretax savings are taxed at the parent's rate, and so $\$ 673$ is deposited into the UTMA account, as was true for the parental account discussed above. For a family with taxable income of $\$ 100,000$, these tax advantages translate into a substantially higher return on the UTMA account than on a parental account. This family yields $\$ 1,453$ in an UTMA account, nearly one-third more than in a parental account.

A 529 savings account confers even greater tax advantages than the UTMA, because the taxes on the inside buildup and withdrawals are not just reduced, they are eliminated. In a state that does not allow families to deduct 529 deposits from taxable income, $\$ 1,000$ of pretax income translates into the same $\$ 673$ deposit that was placed in the parental account and UTMA account. Because no taxes are levied on the inside buildup, by the time the child enters college the family has a slightly higher balance in a 529 than it would in a parental account or UTMA account $(\$ 2,314$ as compared to $\$ 2,135$ and $\$ 2,277$, respectively). The relative advantage of the 529 grows as the family begins to draw down the funds and is exempted from any taxes on the resulting capital gains realizations. Accounting for these taxes, the family nets a $\$ 1,634$ return on its $\$ 1,000$ in pretax savings, 47 percent more than in a parental account and 12 percent more than with an UTMA. The ESA confers the same tax advantages as the 529 without an upfront deduction and therefore yields the same return. ${ }^{24}$

\footnotetext{
${ }^{23}$ In an UTMA, annual asset earnings up to $\$ 750$ are untaxed. For a child younger than 14 , the next $\$ 750$ is taxed at the child's rate and the remaining earnings are taxed at the parents' rate. For children 14 and over, all earnings over $\$ 750$ are taxed at the child's rate. Note that the tax advantages of the UTMA drop as asset holdings (and earnings) grow, since an ever-smaller share of earnings are taxed at a zero rate.

${ }^{24}$ A key difference, however, is that much larger amounts can be deposited in a 529 than can be deposited in an ESA.
} 
The return on these two college savings vehicles is also identical to that on the Traditional IRA. The Traditional IRA is the mirror image of the college savings accounts, because there are no upfront taxes on the $\$ 1,000$ deposit and no taxes on the inside buildup, but withdrawals are taxed as ordinary income. Note that there is no penalty for early withdrawal (before age 591/2) from the Traditional IRA if the funds are used for higher education expenses. The Traditional IRA therefore yields the same return as the ESA and 529, producing a return 47 percent greater than a non-advantaged parental account.

The option with the highest return is a 529 in a state that allows deposits to be deducted from state taxable income. For a given $\$ 1,000$ in pretax income, more can be deposited into this account than is true for a non-deductible 529 or ESA. With the typical state tax rate on earned income of 5.95 percent, the initial deposit is $\$ 718$ rather than the $\$ 673$. Going forward, the tax treatment is the same as for a standard 529 or ESA. The 529 with an upfront deduction yields a return of $\$ 1,811$, or 63 percent more than a nonadvantaged account in the parent's name.

As these calculations make clear, the education savings accounts provide new and substantial tax advantages. The 529 with the upfront reduction offers a higher return than any existing investment option. Further, the 529 and ESA, while yielding the same after-tax return as the Traditional IRA, substantially expand the assets that can be shielded from taxation. Finally, since the 529 has no eligibility requirements, it provides the first opportunity for tax-advantaged saving for those families ineligible for the IRA or ESA due to their incomes or their access to a pension program at work.

\subsection{Calculation of Returns Net of Income Taxes - All Income Groups}

In this section, I examine the advantages of the education savings accounts for a range of household incomes, ranging from the lowest federal tax bracket (household income of $\$ 35,000$ ) to the highest (household income of over $\$ 335,000$ ). The groups and their associated state and federal tax rates on earned income, capital gains, and interest are shown in Table 2.

I first show how returns vary by income in our benchmark, a non-advantaged account held in the name of the parent. In Figure 2, and Table 5, we see that the lowest-income household has the highest 
absolute returns. This is due to this group's relatively low tax rates on two types of income. First, this group's lower marginal tax rates on earned income produce a larger deposit for a given $\$ 1,000$ of pre-tax income: they start with $\$ 773$ in principal, compared to $\$ 572$ for the highest-income family. This difference in the upfront taxation of income accounts for most of the variation across income groups in net returns. Second, the lowest-income household faces the lowest marginal tax rates on capital gains and interest. As a result of these two aspects of the tax code, the highest-income household earns an after-tax return of $\$ 728$ on its pretax savings of $\$ 1,000$, while the lowest-income household earns 2.4 times as much, or $\$ 1,735$.

By eliminating some forms of taxation, the tax-advantaged vehicles flatten this income gradient in after-tax returns. Figures 3 and 4 shows the after-tax return on the ESA and 529 for each income group. Figure 4 shows the returns in dollar terms, while Figure 3 scales the returns relative to the return in the non-advantaged account for that income group. Note that since their returns for the investment scenario laid out earlier are identical, I have collapsed the ESA, 529 without an upfront deduction and the Traditional IRA into one category. It should be recalled, however, that the contribution limits are far higher on the 529 than the ESA or IRA, making the 529 particularly advantageous to those who save above the ESA or IRA limits, or to those participating in a retirement plan at work and above the associated IRA income limits. Also, note that the top two income groups do not qualify for the ESA but do qualify for the 529 .

The largest increases in returns accrue to the highest income group, both in dollar terms (Figure 4) and relative terms (Figure 3). For those in the top federal tax bracket, the 529 with an upfront deduction delivers a net return almost twice as high as that on a non-advantaged account. The 529 without an upfront deduction and the ESA net an after-tax return 70 percent higher than funds held in a nonadvantaged account. For those in the lowest bracket, the proportional increases are much lower: the return on a 529 with an upfront deduction is 26 percent. The corresponding figure is 17 percent for the ESA and 529 with no upfront deduction. Note that the UTMA is of almost no benefit for this lowest-income household, since the child and parent are in the same low tax bracket. 
These calculations make clear that both the relative and absolute advantages of the education savings accounts rise steeply with income. At the bottom of the income distribution, where marginal tax rates are the lowest, the new accounts offer after-tax returns 17 to 26 percent higher than the return on a non-advantaged account. For an initial pretax investment of $\$ 1,000$, this translates into an additional return of $\$ 291$ to $\$ 453$. At the top of the income distribution, the new accounts offer after-tax returns 70 to 91 percent higher than that on a non-advantaged account. For an initial pretax investment of $\$ 1,000$, this translates into an additional return of $\$ 511$ to $\$ 663$.

\section{The Treatment of Assets by the Financial Aid System}

This section turns to the financial aid system I first discuss in general terms the aspects of aid determination that affect net returns to savings. Next, I calculate the impact of the aid system's treatment of assets on returns to various savings vehicles.

\subsection{Overview of the Financial Aid Determination Process}

The federal government distributes need-based aid according to a formula called the Federal Methodology, which I describe in this section. ${ }^{25}$ Most schools use the same formula when distributing their own need-based aid. Eighty-seven percent of four-year public schools, and 57 percent of four-year private schools, use the Federal Methodology to distribute need-based institutional grants. ${ }^{26}$ The aid determination process I describe here is that used for dependent students in academic year 2002-2003. ${ }^{27}$

\footnotetext{
${ }^{25}$ The aid determination process is described in detail by the Department of Education in annual releases of The Student Financial Aid Handbook. The 2002-2003 version used in this paper was downloaded from http://ifap.ed.gov/IFAPWebApp/currentSFAHandbooksPag.jsp on October 17, 2003.

${ }^{26}$ See National Association of Student Financial Aid Administrators and the College Board (2002).

${ }^{27}$ In the past, students gamed their dependency status, since for an independent student family income is not counted in the need determination process, Today, almost all college-age students are considered dependents, as rule changes have made it much more difficult for young people to declare themselves independent.
} 
Families applying for aid fill out the Free Application for Federal Student Aid (FAFSA), which collects detailed information on family income, assets and expenses. A new FAFSA, with current data, must be filled out previous to every academic year for which a student wants aid. Financial data from the FAFSA is put through an algorithm that calculates the expected contribution of the family and of the student toward schooling costs. If the sum of the expected contributions from the family and student is less than anticipated schooling costs, the student is eligible for aid. In the calculation of the expected contribution savings are taxed, because both assets and asset income are considered resources for paying for college.

The resources of the family and the student are calculated separately, and assessed at differing rates in the determination of aid. I start with the family's expected contribution. In the calculation of the family's contribution, an algorithm sums parental income from all sources. Asset income, in the form of dividends, interest, and capital gains, is included. ${ }^{28}$ In particular, the earnings portion of withdrawal from some asset accounts is counted as income by the aid formula. After summing income, the aid algorithm subtracts allowable expenses, including taxes, an allowance based on family size, tuition paid for primary and secondary school, and unusually high medical costs.

To this net income figure is added twelve percent of certain family assets. ${ }^{29}$ From the perspective of the aid system, assets fall into three categories. A first class of assets, notably home equity, pensions, and other retirement vehicles, is completely sheltered from consideration by the aid formula. These assets are not considered available for college expenses. A second class of assets, including 529 savings accounts and ESAs, is considered fully available for college expenses. The first dollar of these assets is assessed in the determination of aid. A final class consists of any assets that do not fall into these first two categories. These assets are partially sheltered from consideration by an asset protection allowance. Each family is allowed a certain level of savings, based on the age of the oldest parent; the assumption is that

\footnotetext{
${ }^{28}$ I discuss below the types of assets for which this source of income is counted and not counted.

${ }^{29}$ If a family is not required to file a 1040 and has an adjusted gross income (AGI) below $\$ 50,000$ then no assets are added at this point.
} 
older parents need a higher level of savings for their approaching retirement. Below this allowance, assets in this class are assumed to be unavailable for schooling costs. The highest allowance is $\$ 70,000$; for a family in which the oldest parent is 50 , the allowance is $\$ 44,000$. Above the allowance, twelve percent of assets is added to the net income figure.

The resulting weighted sum of income, expenses and assets is the family's adjusted available income (AAI). A progressive schedule, with rates ranging from 22 percent to 47 percent, is applied to AAI to determine the expected family contribution (EFC).$^{30}$ The schedule is quite steep: an AAI of $\$ 11,000$ is marginally assessed at 22 percent, while the schedule tops out at an AAI of $\$ 24,000$, which is marginally assessed at 47 percent. In the calculations below, I assume that families are at the top of this schedule.

The expected contribution of the student is calculated analogously to the process just described, with fewer protections for income and assets. All student income above $\$ 1,750$ is assumed to be available for college and is assessed at a rate of 50 percent. There is no asset protection allowance for students. For each year of college, students are expected to contribute 35 percent of their assets.

\subsection{The Treatment of Assets and Asset Income in the Aid Determination Process}

Assets returns are affected twice in the process just described, since both asset balances and asset income are considered available for college expenses. I will first describe the treatment of an asset balance. Consider an entering freshman whose parents have $\$ 45,000$ in financial assets that are not held in retirement accounts or college savings plans. These assets fall into the third category described above, and so are partially sheltered by the asset protection allowance. Assuming the older parent is $50, \$ 44,000$ is protected from consideration by the aid formula and $\$ 1,000$ is subject to assessment. Twelve percent of the $\$ 1,000$ is added to adjusted available income, which is then assessed at 47 percent, and so $5.64(=0.12$

\footnotetext{
${ }^{30}$ Families that are not required to file a 1040 and whose incomes are below $\$ 13,000$ are automatically assigned an EFC of zero.
} 
$x$ 0.47) percent of the $\$ 1,000$ is considered available for the first year of college. Freshman-year aid is reduced by $\$ 56.40$ as a result of this aspect of the aid formula.

If the child goes on for another year of college, and applies again for aid, sophomore year aid is again reduced by 5.64 percent of the remaining asset balance. As a result, the total impact of this $\$ 1,000$ asset on aid received throughout college is a function of the annual assessment on the asset balance $\left(t_{a}\right.$, 5.64 percent in this case) and the number of years spent in college. If a family draws down an equal share of the initial asset balance for each year of college (and, for simplicity, we assume no asset earnings once the child enters college) we can summarize the reduction in aid received over the college career as a result of owning a dollar in assets as of the senior year of high school as follows:

$$
\tau_{a}=\sum_{t=1}^{T} \frac{t}{T} t_{a}
$$

Here, $t$ indexes each year of college for which aid is requested, $T$ is the total number years of college for which aid is requested; $a$ indexes different types of assets. Say the high school senior we are considering ends up spending four years in college, drawing down equal increments of the asset per year for expenses. For this family, each dollar of assets held as of the senior year leads to a reduction in aid over the four years of college of 14.1 cents:

$$
\tau_{a}=\sum_{t=1}^{4} \frac{t}{4} t_{a}=\frac{5}{2} 0.0564=0.141
$$

or 14.1 percent. Note that this is not the full impact of the asset on aid, as we have not allowed the asset to grow while the child is in college, which produces income that goes into the aid formula, nor have we considered that some portion of the withdrawals may consist of earnings, which again produces income that goes into the aid formula. I will consider both of these issues below and in the main calculations of the paper.

I have just described the aid system's treatment of a parental asset. Some savings are considered assets of the child in the calculation of aid eligibility, which changes the annual assessment rate from 5.64 to 35 percent. The second column of Table 6 shows the annual assessment on asset balances for the 
savings vehicles we have been considering throughout the paper. Balances in a 529 savings plan are treated as an asset of the parent in the determination of the aid tax on asset balances. Balances in retirement vehicles are ignored by the aid formula. An ESA is considered by the aid system to be owned by the potential student, as is an UTMA or any other asset in the child's name. ${ }^{31}$ For such assets, the relevant annual assessment on asset balances is 35 percent, rather than 5.64 percent. Further, the first dollar of such assets is assessed at this rate, as there is no asset protection allowance for the student. Over four years of college, the assessment on these assets balances amounts to 87.5 percent:

$$
\tau_{a}=\sum_{t=1}^{4} \frac{t}{4} t_{a}=\frac{5}{2} 0.35=0.875
$$

As the table and these calculations make clear, the aid tax on asset balances varies widely across savings vehicles.

I next describe the aid system's treatment of asset earnings. Like all other sources of income, asset income is considered a financial resource that a family can apply toward college costs, and so increases in asset income lead to decreases in aid. Asset income is considered only if it is realized during a year whose income is considered in the determination of aid. Asset income is assessed with a one-year lag, since it is based on income reported on the previous year's 1040. Freshman-year aid, for example, is based on the FAFSA filed when the student was a high school senior. This FAFSA contains tax return

${ }^{31}$ Department of Education documents for the 2003-2004 school year clearly state that the ESA is to be treated as an asset of the child, which is assessed at the 35 percent rate: "The Education IRA is counted as an asset of the beneficiary" and "Education IRAs have been appropriately renamed education savings accounts; they are considered an investment asset for the student beneficiary (pp. AVG-20 and AVG-19, respectively, in The Student Financial Aid Handbook 2003-2004. This document can be accessed at http://ifap.ed.gov/sfahandbooks/attachments/0304AVGMaster.pdf) This same information is contained in the dozens of financial advising documents, news articles, and financial aid resources for parents, schools and aid professionals that I have consulted. It is also contained in the instructions for completing the online FAFSA.

As of November, 2003, it appears that the Department of Education is moving to improve the treatment of the ESA documented in this chapter. The department has now posted revisions to the online version of The Student Financial Aid Handbook, its reference manual of aid rules. These revisions indicate that, in the future, the ESA will be given the treatment currently applied to the 529 savings plans. This will eliminate the aid tax of over 100 percent that is currently applied to the ESA. See further discussion of implementation of this policy shift in the introduction to this paper. 
data on asset income for the calendar year that spans the spring of the junior year and fall of the senior year of high school. Any earnings received during that period count as income in the determination of aid for freshman year. These earnings might take the form of interest, dividends or capital gains realizations stemming from the sale of stock or liquidation of a mutual fund.

Note that in any account that has been building value for 18 years a substantial portion of the balance consists of unrealized gains. As the account is drawn down for college, these earnings are realized and assessed by the aid formula. In a non-advantaged account, given the investment scenario assumed throughout the paper, unrealized gains represent about 55 percent of account value. When withdrawals are made to pay for college 55 percent of each withdrawal is treated as income.

Any income taxes paid in a given year offset the income taxed by the aid formula. For example, interest earned in a non-advantaged account is taxed by the state and federal governments. Interest adds to adjusted available income, and taxes paid on the interest subtract from it. The aid system therefore assesses asset income net of any income taxes paid on that income.

The last two columns of Table 6 show the assessment rate on asset earnings for the different savings vehicles. I show separately the treatment of earnings accruals and of withdrawals.

For the 529 and ESA, earnings are ignored by the aid system as they accrue; these earnings do not appear on the FAFSA. The earnings portion of withdrawals from the 529 is also ignored by the aid system. However, the earnings portion of withdrawals from the ESA are assessed at 50 percent. ${ }^{32}$ For the Traditional IRA, earnings are ignored by the aid system as they accrue and the entirety of any withdrawal is treated as income and is assessed at the parents' rate of 47 percent. However, any income taxes paid on these withdrawals reduce the amount of income that goes into the aid formula. ${ }^{33}$

\footnotetext{
${ }^{32}$ See p. AVG-17 of US Department of Education (2003).

${ }^{33}$ Personal communication with Anthony Jones, US Department of Education. Also see Chapter 6 of The Student Financial Aid Handbook 2003-2004, which contains the worksheets that detail the treatment various assets and income.
} 


\subsection{Returns Net of Income Taxes and Aid Reductions}

Table 7 shows how reductions in aid affect after-tax returns for various savings vehicles. The first column shows the return on a given savings vehicle for a household that is unaffected by aid policy; these are the returns we have seen in earlier tables. As discussed earlier, asset returns are unaffected by aid policy for two types of families. The first type is extremely needy (with very low financial resources and/or very high schooling costs) and receiving the maximum aid allowed. ${ }^{34}$ The second type of family is not at all needy (with very high financial resources and/or very low schooling costs) and receiving zero aid. For neither family does a marginal change in assets affect aid.

The second column of Table 7 shows returns net of reductions in financial aid induced by asset holdings. I assume, as I have throughout the paper, that the account funds are drawn down over the four years of college. These results are not shown for the top two tax brackets, in which I assume household income is sufficiently high (above $\$ 150,000$ ) that the child is beyond the margin of eligibility of financial aid at even the most expensive institutions. Columns (3) and (4) express the loss in aid as a percent of the asset balance at the start of college and as a percent of the after-tax return, respectively.

The impact on returns is enormous, especially for the UTMA and ESA, for which returns are negative once losses in aid are considered,. Each of these assets is considered by the aid system to belong to the child. As a result, the annual assessment on asset balances held in either of these vehicles is 35 percent, rather than the 5.64 percent applied to the other savings vehicles. When we consider only income taxes, an aid-marginal family with taxable income of $\$ 50,000$ that puts $\$ 1,000$ pretax in an ESA nets a return of $\$ 1,808$. This return is 22 percent higher than if the funds were invested in a non-advantaged account (see Table 4). But once we consider losses of need-based aid, the financial advantage of the ESA disappears. The final return on the $\$ 1,000$ pretax investment, net of income and aid taxes, is $-\$ 1,194$. This family loses all principal and all earnings, plus an additional $\$ 194$, to income taxes and foregone aid. The

\footnotetext{
${ }^{34}$ As already noted, total aid is capped by a student's actual schooling costs, which includes tuition and
} fees plus an allowance for items such as food, rent and other living expenses. 
aid lost due to owning assets in the ESA, expressed as a percentage of the return net of income tax, ranges from 160 percent for the family with $\$ 35,000$ of income to 172 percent for the family with $\$ 100,000$ of income. A similar story holds for the UTMA, with the reduction in returns ranging from 178 to 194 percent.

Since this is such an extraordinary result, I will lay out in detail the losses in aid associated with holding funds in an ESA. Table 8 shows the calculation in detail, for the ESA, for a 529 without an upfront deduction and for an UTMA. As an example, I examine a family with $\$ 100,000$ in income. ${ }^{35}$ In January of year 18, when the child is a high school senior, this family files a financial aid form. At this time the ESA account, which has been gaining value since it was established at year 0 with an after-tax contribution of $\$ 673$, contains $\$ 2,314$; this balance is shown in Column (1) of Table 8 . Thirty-five percent of this balance, or $\$ 810$, is considered available for college costs; this is shown in Column (2). At the end of the year, when the child is a freshman in college, the family draws down $\$ 609$, one-quarter of the endof-year balance [Column (4)]. Seventy-one percent of this amount (\$432) consists of earnings, which is considered income of the child in the calculation of aid and assessed at 50 percent. Aid is therefore reduced by $\$ 216$ due to this withdrawal.

The remaining rows repeat these calculations for the three subsequent years, until the account is emptied. Asset balances are assessed four times, once for each FAFSA that is filed. Withdrawals are assessed just three times; this is because income is recorded on the FAFSA with a one-year lag, and so the final, senior-year withdrawal does not appear on a filed FAFSA. The total reduction in aid is $\$ 2,816$, while the balance at the start of year 18 was $\$ 2,314$. The ratio of these two numbers is the 122 percent shown in Table 7.

The 529 savings plans are not as hard hit by the aid tax, as the aid system considers this asset to belong to the parent rather than to the child. The aid tax on net-of-income-tax returns for the 529 is 57 to 63 percent, lower than that on a non-advantaged account in the name of the parent (63 percent to 81

\footnotetext{
${ }^{35}$ Family income does not affect the aid process depicted in Table 8 , but it is necessary to choose an income tax bracket to pin down the dollar amounts shown therein.
} 
percent). Once we consider aid taxes, the 529, with or without an upfront deduction, nets higher returns than the non-advantaged account, the UTMA or the ESA. In the case of the non-advantaged account, the 529 performs better because its inside buildup is not taxed by the aid system. In the case of the UTMA and ESA, the 529 performs better because the tax on the asset balance is 5.64 percent rather than 35 percent.

\section{Discussion}

The intent of the savings incentives is to increase saving by increasing net returns. The intent of the financial aid system is to give less aid to those with higher income and assets. These two sets of policies inevitably work at cross-purposes, as the financial aid system attempts to tax away any increase in assets and income that the savings incentives create. Unless assets and asset income are completely disregarded, asset returns for aid-marginal families are reduced by the aid determination process. Given this constraint, we can make the aid tax as non-arbitrary as possible. Here, I discuss the results of the paper's analysis in the context of this goal.

\subsection{Asset "Taxes" Greater Than 100 Percent}

It is difficult to infer any reasonable policy goal that is consistent with the aid system's current treatment of the Coverdell, the UTMA, and all assets held in the name of the student. Families that put funds in these vehicles lose all their assets to income taxes and aid reductions; that is, these vehicles face income taxes and "aid taxes" that sum to well over 100 percent. The paper's simulations show that a middleincome family that puts $\$ 1,000$ into a Coverdell loses all of the principal and earnings, plus an additional $\$ 194$, to income and aid taxes. A family that puts funds into the name of the student in an UTMA is even worse off, losing principal and earnings plus an additional \$391. Any asset held in the name of the child faces similar treatment.

Fully taxing away principal and earnings - a tax of 100 percent - is consistent with a very strict, narrow formulation of need: at the time of college attendance, it puts a saving family in the same position 
vis-à-vis the aid system as a non-saving family. ${ }^{36}$ However, taxing away more than principal and earnings is certainly not consistent with this strict formulation of need, as it places the saving family in a worse-off position than the non-saving family, by thousands of dollars if they save at the rate recommended by financial counselors.

\subsection{Sharply Differing Tax Rates on Parents' and Students'Assets}

The differing treatment of assets held by the parent and the student has a very large impact on aid received and net returns, as is shown in Figure 5. This operates counter to the aid system's goal of treating equally families with equal resources, as two families with the same asset levels face vastly divergent tax rates depending on whose name is on the account. A middle-income family (income of $\$ 50,000$ ) that puts funds in the child's name in an UTMA account yields a small income tax advantage - a nine percent increase in the lifetime return (not annualized return), as shown in Table 4. For a family that deposits $\$ 1,000$ of pretax income in an account and leaves it to accrue for 18 years, this translates into a savings of \$133. However, the associated loss in aid more than erases this small gain from gaming the income tax system. Once we consider both the income tax and losses in aid, this family loses $\$ 1,881$ by having the funds in an UTMA account rather than in the parents' name [netting a return of $-\$ 1,391$ versus $\$ 490$, see Column 2 of Table 7]. Further, they end up with far less than they would have had they not saved at all, having lost their principal, their earnings and an additional \$391. Further, the first dollar of funds held in the child's name result in aid reductions, while assets held in the parent's name are protected by an asset allowance. As a result, the average aid tax rate on the parents' assets is well below that on children's assets.

${ }^{36}$ The saving family has forgone consumption to save, and so it is worse off in a lifetime sense than if it had not saved at all when principal and earnings are fully taxed away. Edlin (1993) discusses this and other aspects of the equity of the aid tax. 


\subsection{Sharply Differing Tax Rates on Different Savings Vehicles}

As Table 7 makes clear, the impact of aid policy on asset returns varies wildly, depending on the savings vehicle. A dollar in assets held by the family of a high school senior produces, over a four-year college career, a reduction in need-based aid of 15 cents if the funds are held in a 529 savings plan, 26 to 39 cents if the funds are held in an IRA, about forty cents if the funds are held in a typical mutual fund account in the parent's name, $\$ 1.22$ if they are held in a Coverdell ESA, and \$1.24 if they are held in an UTMA account. We can express these aid reductions relative to after-tax returns on these various savings vehicles. The reduction in aid caused by holding funds in a given vehicle ranges from 19 percent of aftertax returns for the 529 to 200 percent for the UTMA.

As discussed above, in the context of asset ownership by parents and children, such wildlyvarying treatment of assets does not advance the goals of the need-based aid system. It induces an efficiency loss, in that it encourages shifting of assets toward those vehicles that are treated preferentially by the aid system. And it induces a loss in equity, in that it imposes significant losses on those who do not know how to game the system. This leads to a loss of horizontal equity, in that the aid system treats unequally those who have the same asset levels but have made differing strategic choices about where to put the funds.

\subsection{Policy Alternatives}

Two key points emerge from this discussion. First, some assets are treated extremely punitively by the aid system, resulting in those who save losing more than one dollar in aid for each dollar they hold in assets. A second and distinct point is that the treatment of assets is highly inconsistent. I have already explained the efficiency and equity losses induced by these aspects of the aid system. Here I lay out and critique several policy options that address these two points.

There are two main sources of the variable treatment of assets by the aid system: the differential treatment of parents' and children's assets and the differential treatment of different asset types - e.g., retirement accounts, home equity, college savings plans, and non-advantaged accounts. The differential 
treatment of parents' and children's assets accounts for most of the variance in the treatment of assets; for example, because the Coverdell is defined as an asset of the child, it faces an annual assessment rate on asset balances of 35 percent, rather than the 5.64 percent imposed on the 529 savings plans, which are defined as an asset of the parent. Were the Coverdell instead defined as an asset of the parent a dollar held in a Coverdell would lead to a reduction in aid of fifteen cents, the same as the 529 savings plan, rather than $\$ 1.22$. The fact that the first dollar of children's assets is assessed while many parental assets are protected by an allowance that goes as high as $\$ 70,000$ also contributes to the divergence in the treatment of parents' and children's assets. ${ }^{37}$

Pooling parents' and children's assets in aid determination will therefore go far in reducing the variability in the treatment of assets. All children's assets, and not just those of the student applicant, would be included in this pool. Applying what is currently the treatment of parental assets to children's assets is the simplest solution, but this approach would obviously lead to a higher level of aid expenditures, since children's assets would be assessed at a much lower rate. A revenue-neutral alternative would be a new assessment rate on the pooled assets that is the asset-weighted average of the current assessment rates. Note that this pooling of assets would bring children's assets under what is currently the parents' asset protection allowance.

The second issue is how different types of assets are treated. Currently, the value of retirement assets and home equity are completely excluded from aid determination. ${ }^{38}$ All other assets contribute to the net worth considered available for college costs. An alternative is to pool all assets - regular accounts, Coverdells, 529s, UTMAs, retirement assets, home equity - and tax them uniformly in the aid determination process. Under such a system, the aid tax rate on assets would be the same across savings vehicles. Unifying assets in this way would reduce the deadweight loss caused by families shifting assets to avoid the aid tax. It would also eliminate several sources of horizontal inequity. For example,

\footnotetext{
${ }^{37}$ Since the paper's calculations use marginal tax rates rather than average rates they ignore this aspect of the divergence in the treatment of parent's and children's assets.

${ }^{38}$ After-tax withdrawals from retirement funds are treated as available income, however.
} 
homeowners in areas with high real estate values (the East and West coasts) have greater opportunity to shield assets from the aid system than do renters or those in areas with lower real estate values (the middle of the country). Similarly, those who work in jobs that provide access to a $401(\mathrm{k})$ have a greater ability to shield assets than do other workers.

If other aspects of the aid determination process were unchanged, the main effect of pooling all types of assets would be to decrease aid, since it would add retirement assets and home equity to the net worth considered available for paying for college. To maintain the current level of aid spending, the assessment rate on all assets could be reduced below its current maximum of 5.64 percent. Alternatively, the asset protection allowances could be increased so that the total net worth assessed by the aid system remains unchanged.

\section{Conclusion}

This paper has examined the income tax code's most recent experimentation with education policy, in the form of the Coverdell Education Savings Account and the 529 savings plans. Tax incentives for college saving were designed to increase savings by increasing after-tax returns. From the narrow perspective of the income tax code, they have succeeded in increasing after-tax returns. But if we broaden our perspective to include the interaction of the new tax incentives with existing educational policy - in the form of the financial aid system - these policies fail. Families that save for college are potentially subject to taxation not only by federal and state taxing authorities but also by the federal, state and college financial aid systems. As I have shown, the aid tax on savings can extend well up the income distribution, as fairly well-off families can qualify for aid at expensive private institutions.

For families caught in the cross-fire between aid policy and tax policy, the impact on the bottom line is not pretty. A family that heeds advice to save for college in one of the new college savings vehicles can find itself far worse off than if it had simply placed funds in a non-advantaged account in the parents' name. Further, those who put funds in a Coverdell can find themselves worse off than if they had not 
saved at all. These perverse outcomes indicate that greater attention to the interaction of aid and taxes is required if the tax code is to succeed as an instrument for education policy. 


\section{References}

Cerulli Associates (2003). "A Competitive Outlook for 529 Savings Plans.”

Dynarski, Susan (2002). "Loans, Liquidity and Schooling Decisions.” Kennedy School of Government Working Paper.

Edlin, Aaron (1993). "Is College Financial Aid Equitable?” Journal of Economic Perspectives. $7: 2$, pp. $143-158$.

Feldstein, Martin (1995). "Scholarship Rules and Private Savings." American Economic Review $85: 3,552-66$.

National Association of Student Financial Aid Administrators and the College Board (2002). 2001 Survey of Undergraduate Financial Aid Policies, Practices, and Procedures.

U.S. Department of Education (2002). Student Financial Aid Handbook 2002-2003.

U.S. Department of Education (2003). Student Financial Aid Handbook 2003-2004. 
Table 1

Need-Based Aid Receipt, by Income

Dependent Full-Time Undergraduates, Academic Year 1999-2000

Any Need-Based Aid

\begin{tabular}{lcccc} 
& \multicolumn{4}{c}{ Household Income } \\
\cline { 2 - 5 } & $<\$ 40,000$ & $\begin{array}{c}\$ 40,000- \\
70,000\end{array}$ & $\begin{array}{c}\$ 70,000- \\
100,000\end{array}$ & $\$ 100,000+$ \\
\hline Received & $85 \%$ & $62 \%$ & $37 \%$ & $22 \%$
\end{tabular}
(grant, loan, work-study)

Mean if $>0$

$\$ 6,859$

$\$ 5,937$

$\$ 5,371$

$\$ 4,975$

Received

$68 \%$

$9 \%$

$0 \%$

$0 \%$

Pell Grant

Mean if $>0 \quad \$ 2,259 \quad \$ 1,056$

Received

$26 \%$

$24 \%$

$18 \%$

$12 \%$

School Need-Based Grant

Mean if $>0$

$\$ 4,074$

$\$ 5,060$

$\$ 4,793$

$\$ 4,617$

Subsidized Federal Loan,

Received

$52 \%$

$49 \%$

$28 \%$

$12 \%$

Perkins or Subsidized Stafford

Mean if $>0$

$\$ 3,835$

$\$ 3,491$

$\$ 3,322$

$\$ 3,518$

Ineligible for Need-Based Aid, but

Will Qualify if Expected Family Contribution

$0 \%$

$6 \%$

$14 \%$

$8 \%$

Decreases by $\$ 5,000$ or less

Eligible for Need-Based Aid, Room for Need to Increase by $\$ 5,000$ or more if EFC drops

$4 \%$

$39 \%$

$39 \%$

$19 \%$

Total Share on Aid Margin

$4 \%$

$45 \%$

$53 \%$

$27 \%$ 
Table 2

Marginal Tax Rates Used in Calculations

\begin{tabular}{|c|c|c|c|c|c|c|c|c|c|}
\hline \multirow{2}{*}{$\begin{array}{l}\text { Household } \\
\text { Income }\end{array}$} & \multicolumn{3}{|c|}{ Earned Income } & \multicolumn{2}{|c|}{ Capital Gains } & \multicolumn{2}{|c|}{ Interest Income } & \multicolumn{2}{|c|}{ Dividends } \\
\hline & Federal & State & FICA & Federal & State & Federal & State & Federal & State \\
\hline$\$ 35,000$ & $10 \%$ & $5.08 \%$ & $7.65 \%$ & $5 \%$ & $4.41 \%$ & $10 \%$ & $5.08 \%$ & $5 \%$ & $5.08 \%$ \\
\hline$\$ 50,000$ & $15 \%$ & $5.65 \%$ & $7.65 \%$ & $5 \%$ & $4.83 \%$ & $15 \%$ & $5.65 \%$ & $5 \%$ & $5.65 \%$ \\
\hline$\$ 100,000$ & $25 \%$ & $6.29 \%$ & $1.45 \%$ & $15 \%$ & $5.22 \%$ & $25 \%$ & $6.29 \%$ & $15 \%$ & $6.29 \%$ \\
\hline$\$ 150,000$ & $28 \%$ & $6.43 \%$ & $1.45 \%$ & $15 \%$ & $5.61 \%$ & $28 \%$ & $6.43 \%$ & $15 \%$ & $6.43 \%$ \\
\hline$\$ 200,000$ & $33 \%$ & $6.38 \%$ & $1.45 \%$ & $15 \%$ & $5.48 \%$ & $33 \%$ & $6.38 \%$ & $15 \%$ & $6.38 \%$ \\
\hline$\$ 335,000+$ & $35 \%$ & $6.40 \%$ & $1.45 \%$ & $15 \%$ & $5.56 \%$ & $35 \%$ & $6.40 \%$ & $15 \%$ & $6.40 \%$ \\
\hline
\end{tabular}

Notes: Federal rates are 2003 bracket rates. State rates are average of effective 2002 marginal rates calculated from NBER TAXSIM. State averages taken across states that have an income tax. 
Table 3

Age-Based Portfolio Used in Return Calculations

\begin{tabular}{|c|cccccccccc|}
\hline Year: & $\mathbf{1 - 3}$ & $\mathbf{4 - 6}$ & $\mathbf{7 - 8}$ & $\mathbf{9}$ & $\mathbf{1 0}$ & $\mathbf{1 1 - 1 2}$ & $\mathbf{1 3}$ & $\mathbf{1 4 - 1 5}$ & $\mathbf{1 6 - 2 2}$ & $\begin{array}{c}\text { Nominal } \\
\text { Rate of } \\
\text { Return }\end{array}$ \\
\hline Stock Share & $90 \%$ & $85 \%$ & $74 \%$ & $68 \%$ & $59 \%$ & $58 \%$ & $45 \%$ & $42 \%$ & $25 \%$ & $\mathbf{9 \%}$ \\
Bond Share & $10 \%$ & $15 \%$ & $26 \%$ & $32 \%$ & $41 \%$ & $42 \%$ & $55 \%$ & $58 \%$ & $75 \%$ & $\mathbf{4 \%}$ \\
\hline \hline
\end{tabular}


Table 4

Tax Treatment of College Saving Alternatives

\begin{tabular}{|c|c|c|c|c|}
\hline Investment Option & $\begin{array}{c}\text { Income Limit } \\
\text { married, filing jointly }\end{array}$ & $\begin{array}{c}\text { Taxes Paid on Income, } \\
\text { pre-deposit }\end{array}$ & Taxed Paid on Inside Build-up & Taxes Paid at Withdrawal \\
\hline Traditional IRA & $\begin{array}{l}\$ 70,000 \\
\text { No income limit if no work- } \\
\text { related retirement plan. }\end{array}$ & FICA & & $\begin{array}{l}\text { Federal and state on entire } \\
\text { withdrawal }\end{array}$ \\
\hline 529 & & $\begin{array}{l}\text { Federal and state, FICA. } \\
\text { No state taxes if } 529 \text { with } \\
\text { deduction }\end{array}$ & & \\
\hline Coverdell & $\$ 220,000$ & Federal and state, FICA & & \\
\hline UTMA & & Federal and state, FICA & $\begin{array}{l}\text { Federal and state } \\
\text { First } \$ 750 \text { untaxed } \\
\text { Child } 14+: \text { earnings }>\$ 750 \text { at child's rate } \\
\text { Child }<14: \text { next } \$ 750 \text { at child's rate } \& \\
>\$ 1500 \text { at parent's rate }\end{array}$ & $\begin{array}{l}\text { Federal and state on } \\
\text { realized capital gains, } \\
\text { child's rate }\end{array}$ \\
\hline
\end{tabular}


Table 5

After-Tax Return to College Savings Alternatives

\begin{tabular}{|c|c|c|}
\hline & Nominal Return & Return Relative to Parental Account \\
\hline \multicolumn{3}{|c|}{ Non-Advantaged Account, Parent } \\
\hline$\$ 35 \mathrm{~K}$ & $\$ 1,735$ & 1.00 \\
\hline$\$ 50 \mathrm{~K}$ & $\$ 1,485$ & 1.00 \\
\hline$\$ 100 \mathrm{~K}$ & $\$ 1,113$ & 1.00 \\
\hline$\$ 150 \mathrm{~K}$ & $\$ 987$ & 1.00 \\
\hline$\$ 200 \mathrm{~K}$ & $\$ 803$ & 1.00 \\
\hline$\$ 335 \mathrm{~K}+$ & $\$ 728$ & 1.00 \\
\hline \multicolumn{3}{|l|}{ UTMA } \\
\hline$\$ 35 \mathrm{~K}$ & $\$ 1,824$ & 1.05 \\
\hline$\$ 50 \mathrm{~K}$ & $\$ 1,618$ & 1.09 \\
\hline$\$ 100 \mathrm{~K}$ & $\$ 1,453$ & 1.31 \\
\hline$\$ 150 \mathrm{~K}$ & $\$ 1,338$ & 1.36 \\
\hline$\$ 200 \mathrm{~K}$ & $\$ 1,157$ & 1.44 \\
\hline$\$ 335 \mathrm{~K}+$ & $\$ 1,084$ & 1.49 \\
\hline \multicolumn{3}{|c|}{529 Plan (Deduction) } \\
\hline$\$ 35 \mathrm{~K}$ & $\$ 2,188$ & 1.26 \\
\hline$\$ 50 \mathrm{~K}$ & $\$ 1,976$ & 1.33 \\
\hline$\$ 100 \mathrm{~K}$ & $\$ 1,811$ & 1.63 \\
\hline$\$ 150 \mathrm{~K}$ & $\$ 1,683$ & 1.71 \\
\hline$\$ 200 \mathrm{~K}$ & $\$ 1,475$ & 1.84 \\
\hline$\$ 335 \mathrm{~K}+$ & $\$ 1,391$ & 1.91 \\
\hline \multicolumn{3}{|c|}{529 Plan (No Deduction) } \\
\hline$\$ 35 \mathrm{~K}$ & $\$ 2,026$ & 1.17 \\
\hline$\$ 50 \mathrm{~K}$ & $\$ 1,808$ & 1.22 \\
\hline$\$ 100 \mathrm{~K}$ & $\$ 1,634$ & 1.47 \\
\hline$\$ 150 \mathrm{~K}$ & $\$ 1,511$ & 1.53 \\
\hline$\$ 200 \mathrm{~K}$ & $\$ 1,317$ & 1.64 \\
\hline$\$ 335 \mathrm{~K}+$ & $\$ 1,238$ & 1.70 \\
\hline \multicolumn{3}{|l|}{ ESA } \\
\hline$\$ 35 \mathrm{~K}$ & $\$ 2,026$ & 1.17 \\
\hline$\$ 50 \mathrm{~K}$ & $\$ 1,808$ & 1.22 \\
\hline$\$ 100 \mathrm{~K}$ & $\$ 1,634$ & 1.47 \\
\hline$\$ 150 \mathrm{~K}$ & $\$ 1,511$ & 1.53 \\
\hline$\$ 200 \mathrm{~K}$ & $\$ 1,317$ & 1.64 \\
\hline$\$ 335 \mathrm{~K}+$ & $\$ 1,238$ & 1.70 \\
\hline \multicolumn{3}{|c|}{ Traditional IRA } \\
\hline$\$ 35 \mathrm{~K}$ & $\$ 2,026$ & 1.17 \\
\hline$\$ 50 \mathrm{~K}$ & $\$ 1,808$ & 1.22 \\
\hline$\$ 100 \mathrm{~K}$ & $\$ 1,634$ & 1.47 \\
\hline$\$ 150 \mathrm{~K}$ & $\$ 1,511$ & 1.53 \\
\hline$\$ 200 \mathrm{~K}$ & $\$ 1,317$ & 1.64 \\
\hline$\$ 335 \mathrm{~K}+$ & $\$ 1,238$ & 1.70 \\
\hline
\end{tabular}

Notes: Assumes portfolio mix of Table 2, with stock returns of $9 \%$ and bond returns of $4 \%$. One-time investment of $\$ 1,000$ of pretax income with all earnings reinvested. Funds drawn down over the final four years of investment horizon. 
Table 6

Aid System's Treatment of Saving Alternatives in Aid Determination

\begin{tabular}{|l|c|c|c|}
\hline \multicolumn{1}{|c|}{ Investment Option } & $\begin{array}{c}\text { Annual Assessment on } \\
\text { Asset Balance }\end{array}$ & $\begin{array}{c}\text { Annual Assessment on } \\
\text { Earnings Net of Income Tax }\end{array}$ & Assessment of Withdrawals \\
\hline Non-Advantaged Account, Parent & $5.64 \%$ & $47 \%$ of realized earnings net of income tax \\
\hline Traditional IRA & $0 \%$ & $0 \%$ & $47 \%$ of withdrawal net of income tax \\
\hline 529 & $5.64 \%$ & $0 \%$ & None \\
\hline Coverdell & $35 \%$ & $0 \%$ & $50 \%$ of realized earnings \\
\hline UTMA & $35 \%$ & $50 \%$ & $50 \%$ of realized earnings net of income tax \\
\hline
\end{tabular}


Table 7

After-Tax Return to College Savings Alternatives, Net of Financial Aid Losses

\begin{tabular}{|c|c|c|c|c|c|}
\hline & $\begin{array}{c}(1) \\
\text { After-Tax } \\
\text { Return }\end{array}$ & $\begin{array}{c}\text { (2) } \\
\text { After-Tax Return, } \\
\text { Net of Aid Loss }\end{array}$ & $\begin{array}{l}\text { (3) } \\
\text { Return Net of Aid } \\
\text { Loss Relative to } \\
\text { Non-Advantaged } \\
\text { Account, Parent }\end{array}$ & $\begin{array}{c}\text { (4) } \\
\text { Aid Loss As \% of } \\
\text { Asset Balance at } \\
\text { Start of College }\end{array}$ & $\begin{array}{l}\text { (5) } \\
\text { Aid Loss As \% of } \\
\text { After-Tax Return }\end{array}$ \\
\hline \multicolumn{6}{|c|}{ Non-Advantaged Account, Parent } \\
\hline$\$ 35 \mathrm{~K}$ & $\$ 1,735$ & $\$ 635$ & 1.00 & $43 \%$ & $63 \%$ \\
\hline$\$ 50 \mathrm{~K}$ & $\$ 1,485$ & $\$ 490$ & 1.00 & $43 \%$ & $67 \%$ \\
\hline$\$ 100 \mathrm{~K}$ & $\$ 1,113$ & $\$ 267$ & 1.00 & $40 \%$ & $76 \%$ \\
\hline$\$ 150 \mathrm{~K}$ & $\$ 987$ & $\$ 193$ & 1.00 & $39 \%$ & $80 \%$ \\
\hline$\$ 200 \mathrm{~K}$ & $\$ 803$ & - & & - & - \\
\hline$\$ 335 \mathrm{~K}+$ & $\$ 728$ & - & & - & - \\
\hline \multicolumn{6}{|l|}{ UTMA } \\
\hline$\$ 35 \mathrm{~K}$ & $\$ 1,824$ & $-\$ 1,422$ & -2.24 & $124 \%$ & $178 \%$ \\
\hline$\$ 50 \mathrm{~K}$ & $\$ 1,618$ & $-\$ 1,391$ & -2.84 & $124 \%$ & $186 \%$ \\
\hline$\$ 100 \mathrm{~K}$ & $\$ 1,453$ & $-\$ 1,366$ & -5.12 & $124 \%$ & $194 \%$ \\
\hline$\$ 150 \mathrm{~K}$ & $\$ 1,338$ & $-\$ 1,349$ & -6.98 & $124 \%$ & $201 \%$ \\
\hline$\$ 200 \mathrm{~K}$ & $\$ 1,157$ & - & & - & - \\
\hline$\$ 335 \mathrm{~K}+$ & $\$ 1,084$ & - & & - & - \\
\hline \multicolumn{6}{|c|}{529 Plan (Deduction) } \\
\hline$\$ 35 \mathrm{~K}$ & $\$ 2,188$ & $\$ 1,772$ & 2.79 & $15 \%$ & $19 \%$ \\
\hline$\$ 50 \mathrm{~K}$ & $\$ 1,976$ & $\$ 1,587$ & 3.24 & $15 \%$ & $20 \%$ \\
\hline$\$ 100 \mathrm{~K}$ & $\$ 1,811$ & $\$ 1,444$ & 5.41 & $15 \%$ & $20 \%$ \\
\hline$\$ 150 \mathrm{~K}$ & $\$ 1,683$ & $\$ 1,333$ & 6.90 & $15 \%$ & $21 \%$ \\
\hline$\$ 200 \mathrm{~K}$ & $\$ 1,475$ & - & & - & - \\
\hline$\$ 335 \mathrm{~K}+$ & $\$ 1,391$ & - & & - & - \\
\hline \multicolumn{6}{|c|}{529 Plan (No Deduction) } \\
\hline$\$ 35 \mathrm{~K}$ & $\$ 2,026$ & $\$ 1,631$ & 2.57 & $15 \%$ & $19 \%$ \\
\hline$\$ 50 \mathrm{~K}$ & $\$ 1,808$ & $\$ 1,441$ & 2.94 & $15 \%$ & $20 \%$ \\
\hline$\$ 100 \mathrm{~K}$ & $\$ 1,634$ & $\$ 1,290$ & 4.84 & $15 \%$ & $21 \%$ \\
\hline$\$ 150 \mathrm{~K}$ & $\$ 1,511$ & $\$ 1,183$ & 6.13 & $15 \%$ & $22 \%$ \\
\hline$\$ 200 \mathrm{~K}$ & $\$ 1,317$ & - & & - & - \\
\hline$\$ 335 \mathrm{~K}+$ & $\$ 1,238$ & - & & - & - \\
\hline \multicolumn{6}{|l|}{ ESA } \\
\hline$\$ 35 \mathrm{~K}$ & $\$ 2,026$ & $-\$ 1,209$ & -1.90 & $122 \%$ & $160 \%$ \\
\hline$\$ 50 \mathrm{~K}$ & $\$ 1,808$ & $-\$ 1,194$ & -2.44 & $122 \%$ & $166 \%$ \\
\hline$\$ 100 \mathrm{~K}$ & $\$ 1,634$ & $-\$ 1,182$ & -4.43 & $122 \%$ & $172 \%$ \\
\hline$\$ 150 \mathrm{~K}$ & $\$ 1,511$ & $-\$ 1,174$ & -6.08 & $122 \%$ & $178 \%$ \\
\hline$\$ 200 \mathrm{~K}$ & $\$ 1,317$ & - & & - & - \\
\hline$\$ 335 \mathrm{~K}+$ & $\$ 1,238$ & - & & - & - \\
\hline \multicolumn{6}{|c|}{ Traditional IRA } \\
\hline$\$ 35 \mathrm{~K}$ & $\$ 2,026$ & $\$ 987$ & 1.55 & $33 \%$ & $51 \%$ \\
\hline$\$ 50 \mathrm{~K}$ & $\$ 1,808$ & $\$ 844$ & 1.72 & $31 \%$ & $53 \%$ \\
\hline$\$ 100 \mathrm{~K}$ & $\$ 1,634$ & $\$ 730$ & 2.74 & $27 \%$ & $55 \%$ \\
\hline$\$ 150 \mathrm{~K}$ & $\$ 1,511$ & $\$ 649$ & 3.36 & $26 \%$ & $57 \%$ \\
\hline$\$ 200 \mathrm{~K}$ & $\$ 1,317$ & - & & - & - \\
\hline$\$ 335 \mathrm{~K}+$ & $\$ 1,238$ & - & & - & - \\
\hline
\end{tabular}


Table 8: Detailed Aid Calculations

Loss in Aid for Family Holding Various Assets

\section{Coverdell ESA}

\begin{tabular}{|c|c|c|c|c|c|}
\hline & Loss of Aid due to & & & Loss of Aid due to & \\
\hline $\begin{array}{c}\text { Balance, } \\
\text { Start of Year }\end{array}$ & $\begin{array}{l}\text { Asset Balance, } \\
\text { 35\% of Start-of- } \\
\text { Year Balance }\end{array}$ & $\begin{array}{l}\text { Balance, } \\
\text { End of Year }\end{array}$ & $\begin{array}{l}\text { Withdrawal, } \\
\text { End of Year }\end{array}$ & $\begin{array}{l}\text { Asset Income, } \\
50 \% \text { of After-Tax } \\
\text { Realized Earnings }\end{array}$ & $\begin{array}{l}\text { Total } \\
\text { Loss of } \\
\text { Aid }\end{array}$ \\
\hline
\end{tabular}

(1)

(2)

(3)

(4)

(5)

(6)

\begin{tabular}{|c|c|c|c|c|c|c|c|c|c|c|c|}
\hline Year 18 & $\$$ & 2,314 & $\$$ & 810 & $\$$ & 2,435 & $\$$ & 609 & $\$$ & 216 & \\
\hline Year 19 & $\$$ & 1,826 & $\$$ & 639 & $\$$ & 1,922 & $\$$ & 641 & $\$$ & 227 & \\
\hline Year 20 & $\$$ & 1,282 & $\$$ & 449 & $\$$ & 1,349 & $\$$ & 674 & $\$$ & 239 & \\
\hline Year 21 & $\$$ & 674 & $\$$ & 236 & $\$$ & 710 & $\$$ & 710 & & & \\
\hline TOTAL & & & $\$$ & 2,134 & & & & & $\$$ & 682 & $\$ 2,816$ \\
\hline
\end{tabular}

529, No Upfront Deduction

\begin{tabular}{|c|c|c|c|c|c|c|}
\hline & $\begin{array}{c}\text { Balance, } \\
\text { Start of Year } \\
\text { (1) }\end{array}$ & $\begin{array}{l}\text { Loss of Aid due to } \\
\text { Asset Balance, } \\
5.64 \% \text { of Start-of- } \\
\text { Year Balance } \\
\text { (2) }\end{array}$ & $\begin{array}{c}\text { Balance, } \\
\text { End of Year } \\
\text { (3) }\end{array}$ & $\begin{array}{l}\text { Withdrawal, } \\
\text { End of Year } \\
\text { (4) }\end{array}$ & $\begin{array}{l}\text { Loss of Aid due } \\
\text { Asset Income, } \\
\text { none } \\
\text { (5) }\end{array}$ & $\begin{array}{l}\text { Total } \\
\text { Loss of } \\
\text { Aid } \\
\text { (6) }\end{array}$ \\
\hline Year 18 & $\$ \quad 2,314$ & 130 & $\$ \quad 2,435$ & $\$ \quad 609$ & $\$$ & \\
\hline Year 19 & 1,826 & 103 & 1,922 & 641 & $\$$ & \\
\hline Year 20 & 1,282 & 72 & 1,349 & 674 & $\$$ & \\
\hline Year 21 & 674 & 38 & 710 & 710 & & \\
\hline TOTAL & & 343 & & & $\$$ & 343 \\
\hline
\end{tabular}

\section{UTMA}

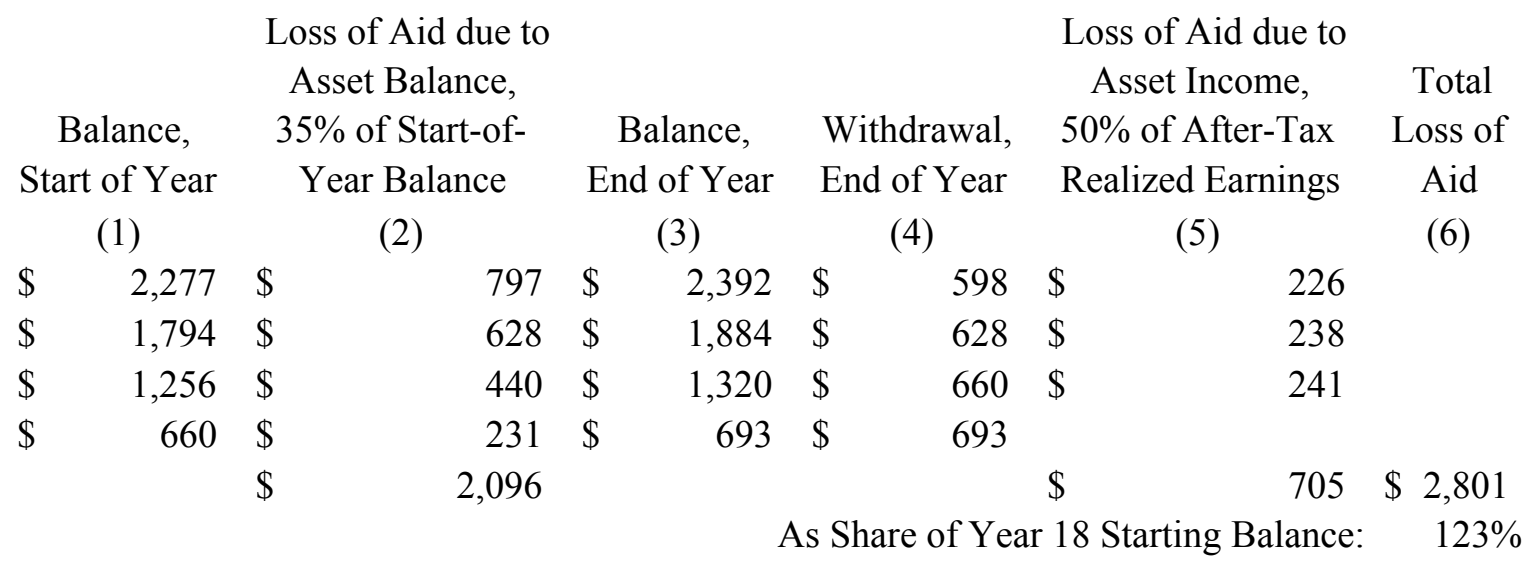

Note: $68-71 \%$ of withdrawals consist of unrealized earnings. Family has household income of $\$ 100,000$. 
Figure 1:

After-Tax Return to College Savings Options

nominal return to $\$ 1,000$ of pretax savings, household taxable income of $\$ 100,000$

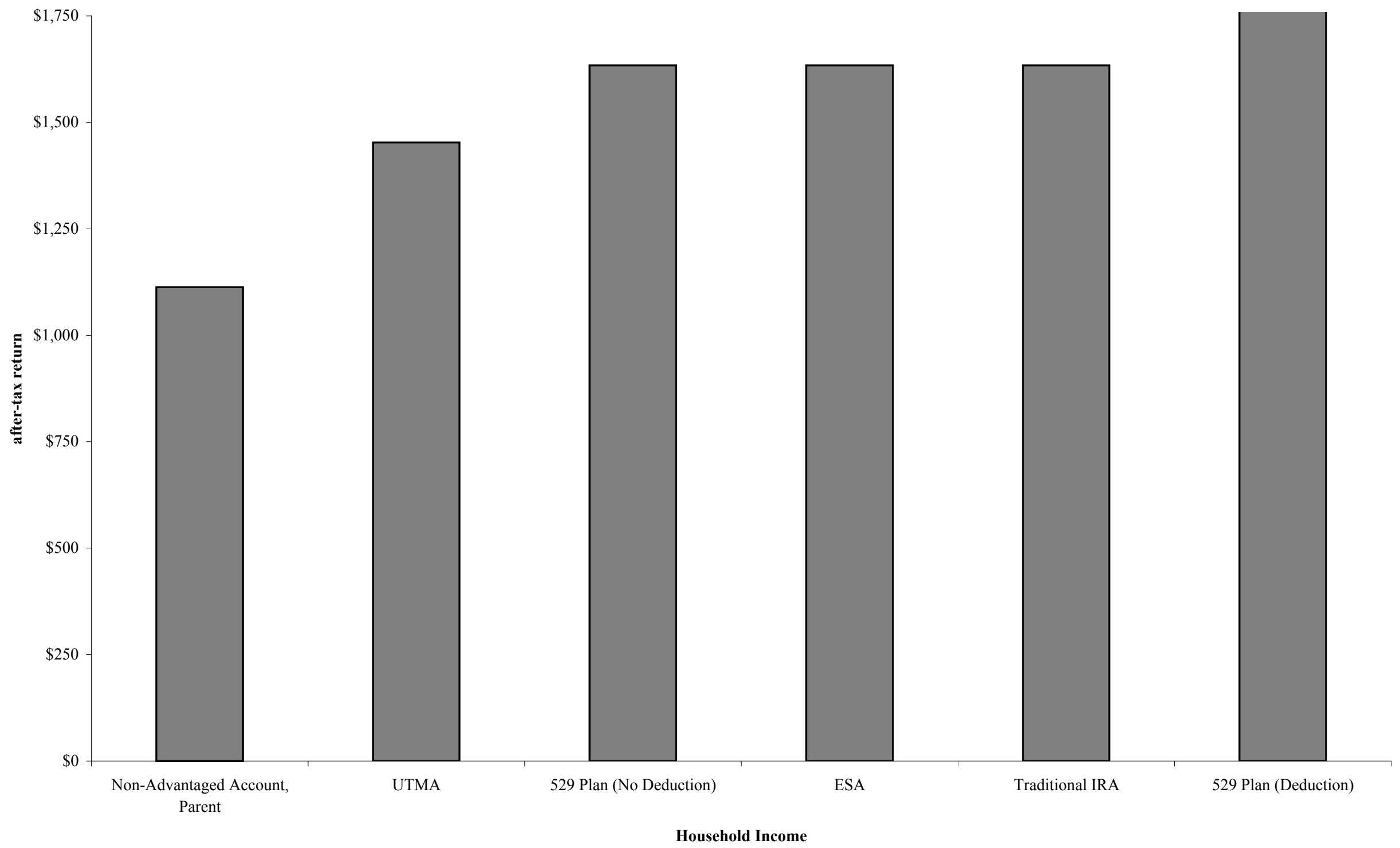

Notes: Assumes portfolio mix of Table 3, with stock returns of $9 \%$ and bond returns of $4 \%$. One-time investment of $\$ 1,000$ of pretax income with all eanrings reinvested. Funds drawn down over the final four years of investment horizon. 
Figure 2:

After-Tax Return to Non-Advantaged Account Held in Name of Parent nominal return to $\$ 1,000$ of pretax savings

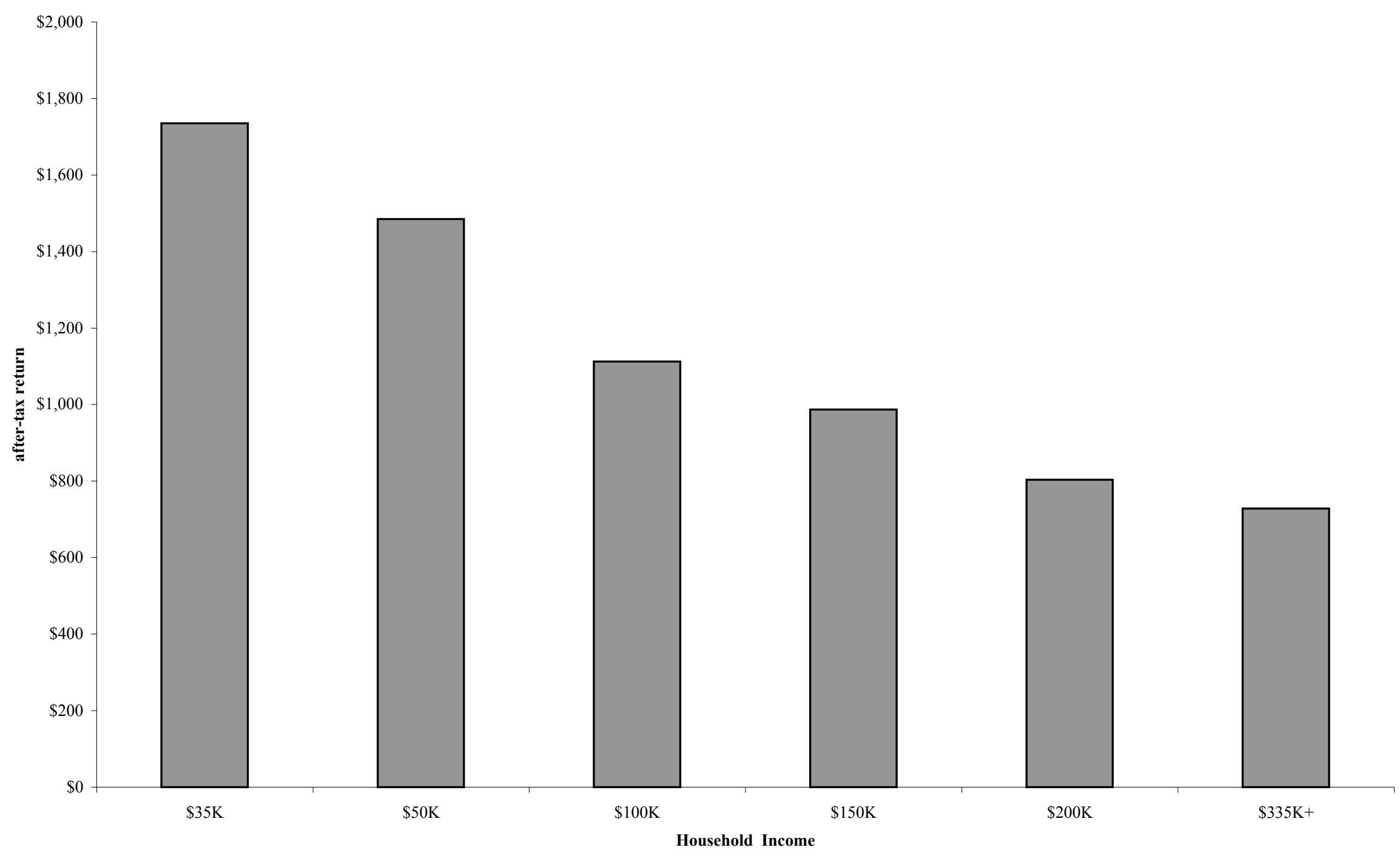


Figure 3:

After-Tax Return to College Saving Options

Relative to Non-Advantaged Account Held in Name of Parent

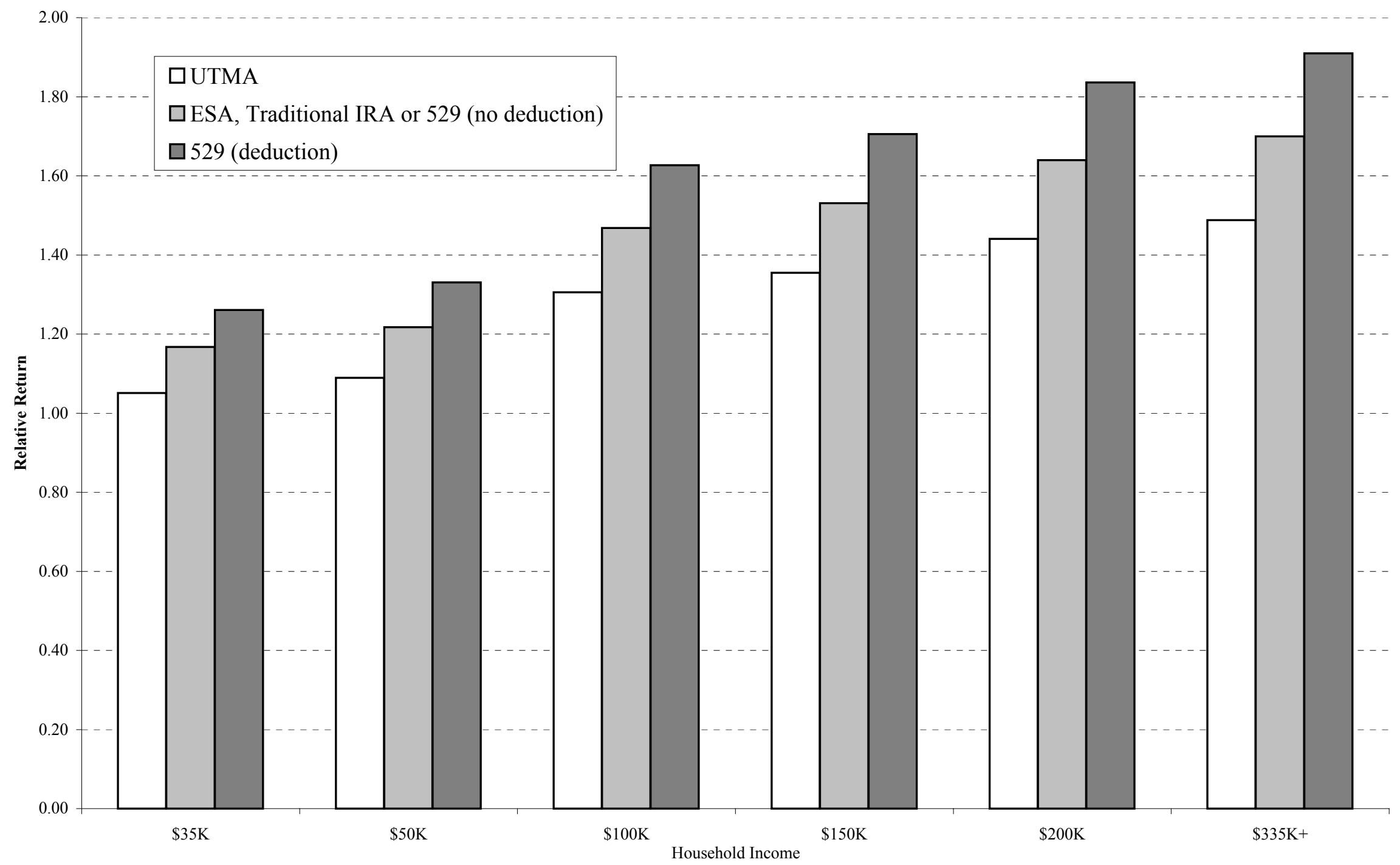

Notes: Assumes portfolio mix of Table 3, with stock returns of $9 \%$ and bond returns of $4 \%$. One-time investment of $\$ 1,000$ of pretax income with all earnings reinvested. Funds drawn down over the final four years of investment horizon. 
Figure 4

After-Tax Return to College Saving Options

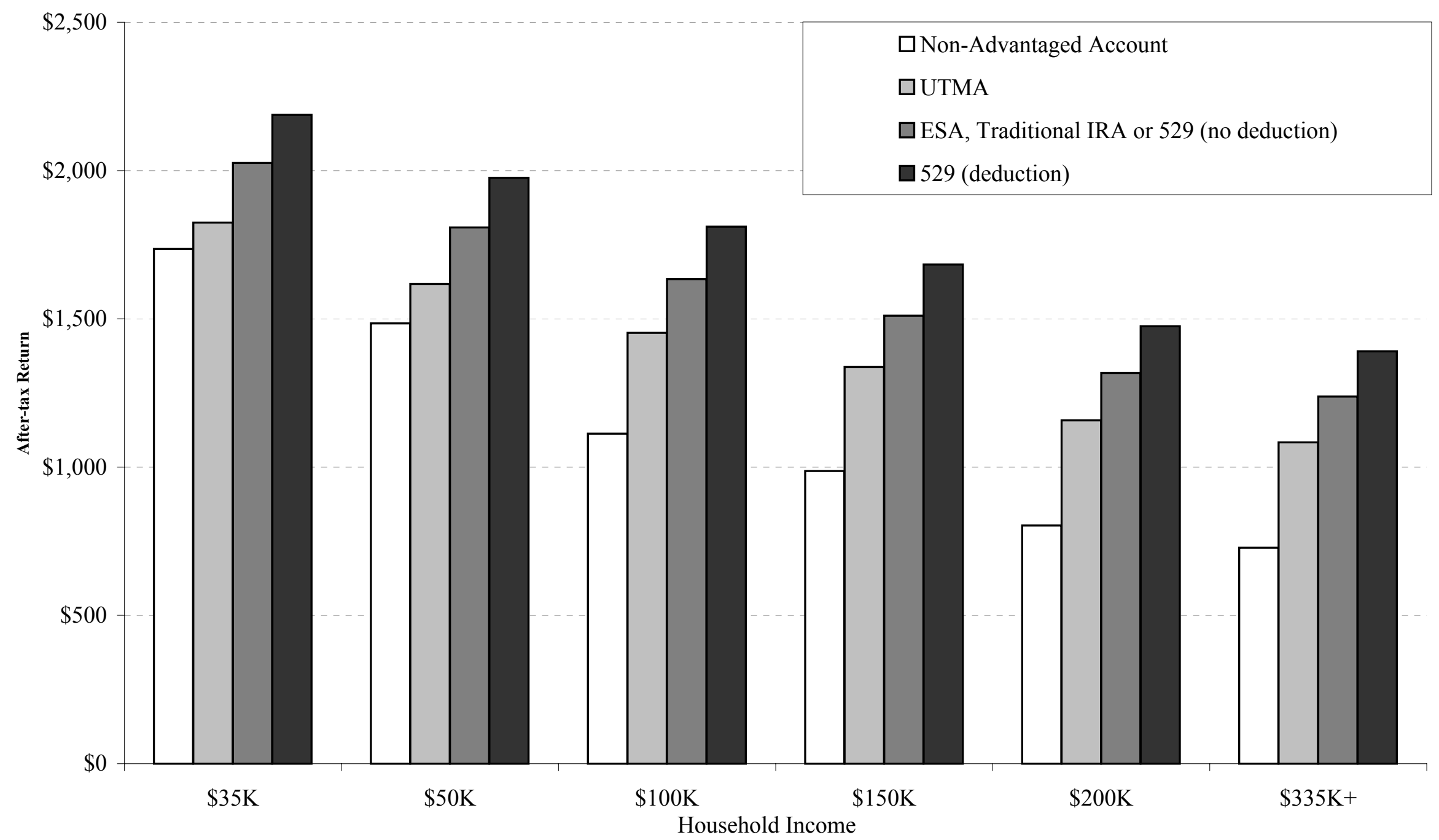

Notes: Assumes portfolio mix of Table 3, with stock returns of $9 \%$ and bond returns of $4 \%$. One-time investment of $\$ 1,000$ of pretax income with all earnings reinvested. Funds drawn down over the final four years of investment horizon. 
Figure 5

Return to College Saving Options, Net of Aid Lost and Income Tax

Assumes those in bottom four brackets are on aid margin; in top two brackets, assumed aid tax is zero

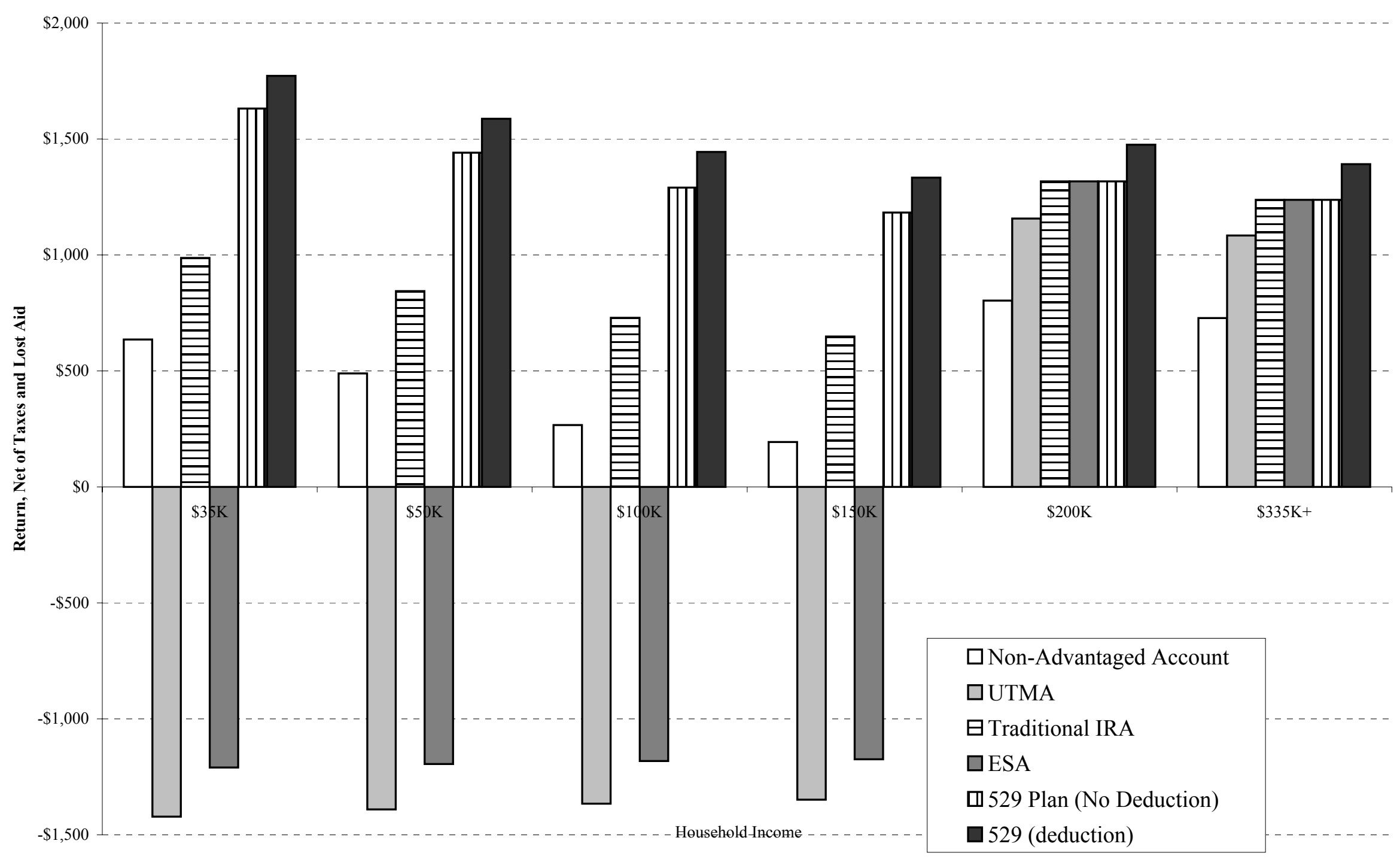

